


\section{CEO FOREWORD}

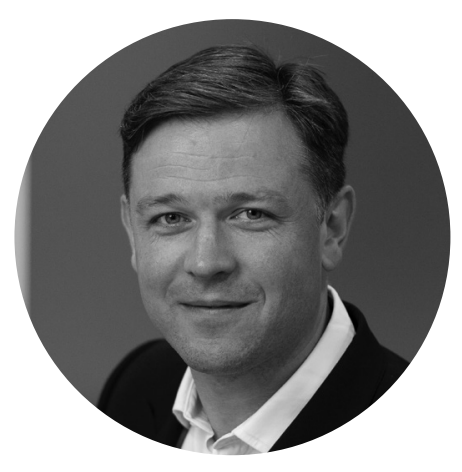

The current global health crisis shows resiliency in supply chains and business models - the ability to adapt to and survive shocks and disruptions - is more essential than ever. The climate crisis is a 'threat multiplier' and makes future economic shocks more likely. Measuring and managing environmental risks through disclosure helps companies to build resiliency and plan for the future.

Climate change is not a distant, potential threat. It is here right now, and already affecting millions of lives across the globe. The Australian bushfires, which started raging in late 2019, have affected nearly 10 million people, including at least 28 human lives that have been lost. This is just one example of recent extreme weather events made more likely by climate change.

The most devastating impact of climate change and extreme weather is always going to be loss of human life, but its impact on ecosystems, communities and the global economy can be dire too. In 2019, CDP analysis found that 215 of the biggest global companies estimate the financial implications of climate risks to be close to US\$1trillion, including US\$250 billion worth of 'stranded assets', at potential risk of being made economically unviable.

The cost of exceeding a temperature rise of 1.5 degrees Celsius - the proposed "guard rail" of safety by the Intergovernmental Panel on Climate Change (IPCC) - could be catastrophic. It would have grave implications on water and food security, living standards, the economy and human health for our generation, and generations to come. In economic terms the difference between 1.5 and 2 degrees is estimated at $\$ 15$ trillion in damage. We cannot afford to dither and delay substantive action any longer.

2020 is a critical year. Five years on from the Paris Agreement, the time has come for national governments to upgrade their ambition to reduce emissions through their national plans. This year needs to herald the start of a super decade of climate action, cutting emissions in half, to give any chance of limiting global warming to $1.5^{\circ} \mathrm{C}$.

And we are already seeing great examples of environmental leadership, with forward-thinking companies proactively taking action. The Science Based Targets initiative has snowballed into a global phenomenon, with more than 750 of the world's biggest companies setting emissions reduction targets that are grounded in climate science. Likewise, corporate demand for renewable power is rapidly growing with $220+$ companies now working towards $100 \%$ renewable electricity.

Transparency is the foundation for meaningful climate action. In 2019, more companies than ever before $-8,400+$ representing over $50 \%$ of global market capitalization - disclosed through CDP, enabling them to comply with the Task Force on Climate-related Financial Disclosures (TCFD). Disclosure of quality data leads to smarter decisions and informs investors, companies and governments of the actions they need to take. It's encouraging to see more companies setting longer-term targets; our data will be key to seeing how they are performing against these over time.

But growing corporate action is not enough. Governments must urgently step up their ambition to give business the clarity and confidence they need to invest in the zerocarbon future. Those who act first on climate will seize the benefits of the transition. CDP will play its part by continuing to set the standard, and providing the tools to help us achieve it together. 2020 must be the year we all play our part to ramp up worldwide ambition on climate without delay.

\section{Paul Simpson}

CEO, CDP 


\section{SPONSOR FOREWORD}

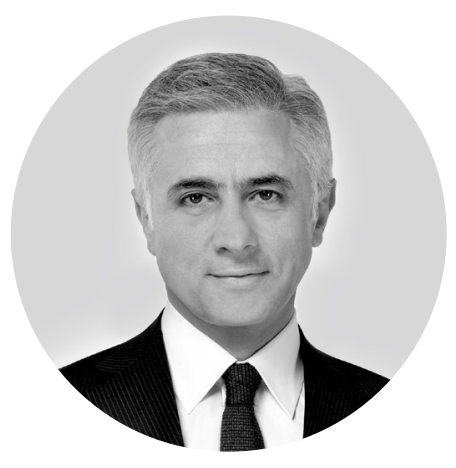

$\nabla \nabla$

Today, the business world is more than capable of changing the world for better and more prosper. Our impact is undeniably huge. Therefore, we are grateful for all companies in Turkey who respond to CDP and try to manage their environmental risks and opportunities.
Our planet warns us about the severity of the natural disasters which are triggered mostly by extreme weather events that occurred all around the world in 2019. Especially flood levels, earthquakes and hurricanes have affected many people and left them homeless. During the first half of the year, more than 10 million displacement have been recorded because of cyclones and flooding activities and more than 7 million people have lost their homes while the other half of the year has resulted around 22 million new displacement due to the new extreme weather events around the globe. Moreover, 15 extreme weather disasters are amplified by the climate change and cost humanity at least a billion dollars in each case. Seven of the events on the list cost over \$10 each in 2019.

According to the Global Risk Report 2020 by the World Economic Forum (WEF), for the first time, top five risks that the world is facing, both the level of possibility and impact, are all environment and climate change related. Based on the United Nations World Economic Situation and Prospects Report, $65 \%$ of 131 weather events were triggered through the devastating effects of climate change in the last six years. While we are all trying to understand how to tackle these issues, we have encountered with a global outbreak at the beginning of 2020 that no one could ever predict. COVID-19 virus that has affected the whole world, have deeply impacted our habits, global economy, business world and supply chain. This global outbreak that brought life to a standstill showed us how devastating our impact on the ecosystem can be.

Although we have changed our lives radically, problems threatening the humanity continue to exist. Today, we are mostly making pandemicfocused decisions and overlook the fact that the environmental and social threats will cause us to encounter such crises even more. Climate crisis is still a big part of our life as an urgency that continues to exist. Every ill-thought-out short-term step that we will take to recover the economy, will lead us to similar crises.

We have all witnessed how quickly the nature responds to the drastic measures taken worldwide. Nature is ready to cooperate, as long as we show the same dedication and determination to tackle other problems. We have to see this "natural disaster" phase as an opportunity to battle with climate crisis. In order to manage the environmental and social risks in the best way and to fully benefit from the opportunities, the new order we will establish has to be with a focus of sustainability. As the business world we have to continue to keep this issue at the top of our agendas. We need financial and emotional collaborations more than ever.

According to the United Nations Adaptation Finance Gap Report, adaptation cost for the climate change will range between $\$ 140-300$ billion per year by 2030. Although public sector contribution is already ensured, there is a huge gap in developing countries that needs to be addressed by the help of private sector players.

During these challenging times working from our homes using technological opportunities, as the business world, we need to work in cooperation to move our economy and our country to a better and more prosperous state. There is no problem that we cannot overcome through learning from each other and creating synergies. Therefore, we are truly grateful to all companies that respond to CDP. Each response will be a new milestone for our collective battle against climate change through increasing our capability in cooperation, sharing responsibilities and setting ambitious targets. We hope to see more responding companies in the future.

\section{Recep Baştuğ}

CEO, Garanti BBVA 


\section{INTRODUCTION}

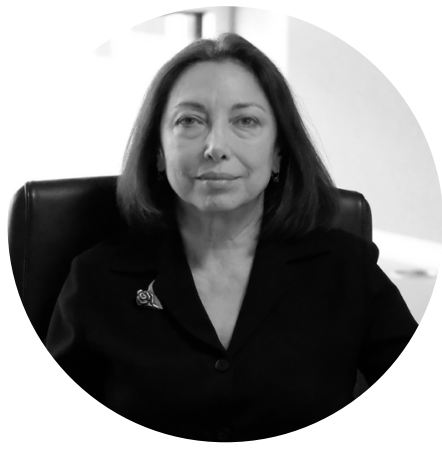

$\nabla \nabla$

Turkey's CDP leader companies that have shown state of the art performance over the past ten years are a source of great inspiration for the late comers. They now have a greater mission; inspiring the policy makers.

\section{Climate Action in the Time and Aftermath of Coronavirus}

Ten years after we launched the CDP Climate Change Program in Turkey, the Planet Earth has briefly shut down to deal with the novel coronavirus. Finding a balance between an effective public-health response and the level of economic slowdown has become and remained a top priority for policy makers and corporate managers.

As the world faces the threat of a global recession, the pandemic may shift global attention away from addressing climate change. There is a great risk of policy makers to scale back their climate goals on the basis that the shutdown has reduced the emissions. The temporary reduction in emissions due $(17.4 \%$ in Turkey), which are expected to rise very quickly in the aftermath the crises, is not going to change the likelihood of future climate shocks. The key issue is to acknowledge that climate change and pandemics are both systemic risks and both require urgent response. Coronavirus is an immediate threat, while climate change, although it is already affecting lives across the world, will unfold over decades.

The period after the COVID-19 crisis, therefore, could determine whether we can meet or miss the 2015 Paris Agreement targets. There are reasons to be optimistic. In fighting against the COVID-19, governments appreciated the value of the worldwide coordinated action, easing tensions between national interests. Second, governments are more in control of the economy as they set the rules for economic recovery. Low carbon, high growth recovery requires a policy package that quickly creates jobs and economic demand, produces steady growth, and at the same time accelerates the uptake of zero carbon technologies. Tax credits, subsidies, loans, loan guarantees, grants and equity participations can all have a green recovery compass. An economic policy paper co-authored by economists from the University of Cambridge, University of Oxford and London School of Economics and Political Science identifies five policies with high potential on both economic multiplier and climate impact metrics: clean physical infrastructure, building efficiency retrofits, investment in education and training, natural capital investment, and clean R\&D or rural support.

It is time for uniting businesses and governments to act for a zero carbon, resilient economy. The Green Recovery Alliance that bring together 12 environment ministers from EU countries, 37 CEOs and business associations, 50 bank and insurance CEOs suggests that it may happen. Not all governments, however, have foresight. Policy involvement that counterbalance for rule makers' reluctance or ignorance is a must for companies that have set a sustainable trajectory for their businesses.

Turkey's CDP leader companies that have shown state of the art performance over the past ten years are a source of great inspiration for the late comers. They now have a greater mission; inspiring the policy makers.

\section{Melsa Ararat}

Director, Sabancı University Corporate Governance Forum 


\section{CONTENTS}

6 RESPONDING COMPANY LIST / CLIMATE CHANGE / TURKEY 2019

7 RESPONDING COMPANY LIST / WATER SECURITY / TURKEY 2019

8 SNAPSHOT / CLIMATE CHANGE / TURKEY 2019

9 SNAPSHOT / WATER SECURITY / TURKEY 2019

10 KEY FINDINGS / CLIMATE CHANGE / TURKEY 2019

11 KEY FINDINGS / WATER SECURITY / TURKEY 2019

12 COMPANY RESPONSE SUMMARY / CLIMATE CHANGE / TURKEY 2019

14 COMPANY RESPONSES OVERVIEW / CLIMATE CHANGE / TURKEY 2019

26 COMPANY RESPONSE SUMMARY / WATER SECURITY / TURKEY 2019

28 COMPANY RESPONSES OVERVIEW / WATER SECURITY / TURKEY 2019

39 CDP TURKEY LEADERS / 2019

40 CDP SCORING METHODOLOGY

42 RESPONSE STATUS / CLIMATE CHANGE / TURKEY 2019

45 RESPONSE STATUS / WATER SECURITY / TURKEY 2019

47 CDP PARTNER IN TURKEY 


\section{RESPONDING COMPANY LIST}

\section{CLIMATE CHANGE / TURKEY 2019}

\section{Official Investor Sample}

AFYON ÇIMENTO SANAYI T.A.Ş.

AKBANK T.A.Ş.

AKENERJI ELEKTRIK ÜRETIM A.Ş.

AKSA AKRILIK KIMYA SANAYII A.Ş.

ALBARAKA TÜRK KATILIM BANKASI A.Ş.

ANADOLU CAM SANAYII A.Ş.

ANADOLU EFES BIRACILIK VE MALT SANAYIi A.Ş.

ARÇELIK A.Ş.

ASELSAN ELEKTRONIK SANAYI VE TICARET A.Ş.

COCA-COLA IÇECEK A.Ş.

ENERJISA ENERJI A.Ş.

ENKA INŞAAT VE SANAYI A.Ş.

FORD OTOMOTIV SANAYI A.Ş.

KARDEMIR KARABÜK DEMIR ÇELIK SANAYI VE TICARET A.Ş.

KORDSA TEKNIK TEKSTIL A.Ş.

MIGROS TICARET A.S.

NETAŞ TELEKOMÜNIKASYON A.Ş.

PEGASUS HAVA TAŞIMACILIĞI A.Ş.

SABANCI HOLDING A.Ş.

SODA SANAYI A.Ş.

ŞEKERBANK T.A.Ş.

T.GARANTI BANKASI A.S.

T.iş BANKASI A.Ş.

TRAKYA CAM SANAYII A.S.

T.SINAI KALKINMA BANKASI A.Ş.

T.ŞIŞE VE CAM FABRIKALARI A.Ş.

TAV HAVA LIMANLARI HOLDING A.Ş.

TEKFEN HOLDING A.Ş.

TOFAŞ TÜRK OTOMOBIL FABRIKASI A.Ş.

TURKCELL ILETIŞIM HIZMETLERI A.Ş.

TÜRK TELEKOMÜNIKASYON A.Ş.

TÜRKIYE HALK BANKASI A.Ş.

TÜRKIYE KALKINMA VE YATIRIM BANKASI A.Ş.

TÜRKIYE VAKIFLAR BANKASI T.A.O.

ÜLKER BISKÜVI SANAYI A.Ş.

VESTEL ELEKTRONIK SANAYI VE TICARET A.Ş.

YAPI VE KREDI BANKASI A.Ş.

ZORLU ENERJI ELEKTRIK ÜRETIM A.Ş,

\section{Self-Selected Companies}

AKÇANSA ÇIMENTO SANAYI VE TICARET A.Ş.

BRISA BRIDGESTONE SABANCI LASTIK SAN. VE TIC. A.Ş.

ÇELEBI HAVA SERVISI A.Ş.

ÇIMSA ÇIMENTO SANAYIi VE TICARET A.Ş.

DURAN DOĞAN BASIM VE AMBALAJ A.Ş.

EKOTEN SANAYI VE TEKSTIL A.Ş.

ETI SODA A.S.

IHLAS EV ALETLERI IMALAT SANAYI VE TICARET A.Ş.

KAYSERI ULAŞIM A.Ş.

PINAR ENTEGRE ET VE UN SANAYII A.Ş.

PINAR SÜT MAMULLERI SANAYIi A.Ş.

POLISAN HOLDING A.Ş.

SUN TEKSTIL SANAYI VE TICARET A.Ş.

VESTEL BEYAZ EŞYA SANAYI VE TICARET A.Ş.

YÜNSA YÜNLÜ SANAYI VE TICARET A.Ş.

ZORLU DOĞAL ELEKTRIK ÜRETIMI A.Ş. 


\section{RESPONDING COMPANY LIST}

\section{WATER SECURITY / TURKEY 2019}

\section{Official Investor Sample}

AFYON ÇIMENTO SANAYI T.A.Ş.

AKENERJI ELEKTRIK ÜRETIM A.Ş.

AKSA AKRILIK KIMYA SANAYII A.Ş.

ARÇELIK A.Ş.

BRISA BRIDGESTONE SABANCI LASTIK SAN. VE TIC. A.S.

COCA-COLA IÇECEK A.Ş.

ÇIMSA ÇIMENTO SANAYIi VE TICARET A.Ş.

ENKA INŞAAT VE SANAYI A.Ş.

FORD OTOMOTIV SANAYI A.Ş.

KORDSA TEKNIK TEKSTIL A.Ş.

MIGROS TICARET A.Ş

POLISAN HOLDING A.Ş.

TEKFEN HOLDING A.Ş.

TOFAŞ TÜRK OTOMOBIL FABRIKASI A.Ş.

ÜLKER BISKÜVI SANAYI A.Ş.

VESTEL BEYAZ EŞYA SANAYI VE TICARET A.Ş.

VESTEL ELEKTRONIK SANAYI VE TICARET A.Ş.

ZORLU ENERJI ELEKTRIK ÜRETIM A.Ş.

\section{Self-Selected Companies}

AKÇANSA ÇIMENTO SANAYI VE TICARET A.Ş.

ALBARAKA TÜRK KATILIM BANKASI A.Ş.

DURAN DOĞAN BASIM VE AMBALAJ A.Ş.

ETI SODA A.S.

IHLAS EV ALETLERI IMALAT SANAYI VE TICARET A.Ş.

PINAR ENTEGRE ET VE UN SANAYII A.Ş.

PINAR SÜT MAMULLERI SANAYII A.Ş.

SABANCI HOLDING A.Ş.

ŞEKERBANK T.A.Ş.

T.GARANTI BANKASI A.Ş.

TÜRKIYE HALK BANKASI A.Ş.

YAPI VE KREDI BANKASI A.Ş.

YÜNSA YÜNLÜ SANAYI VE TICARET A.S.

ZORLU DOĞAL ELEKTRIK ÜRETIMI A.Ş.

Number of responding companies since 2011

60

50

40

30

20

10

0

Water - Official Sample

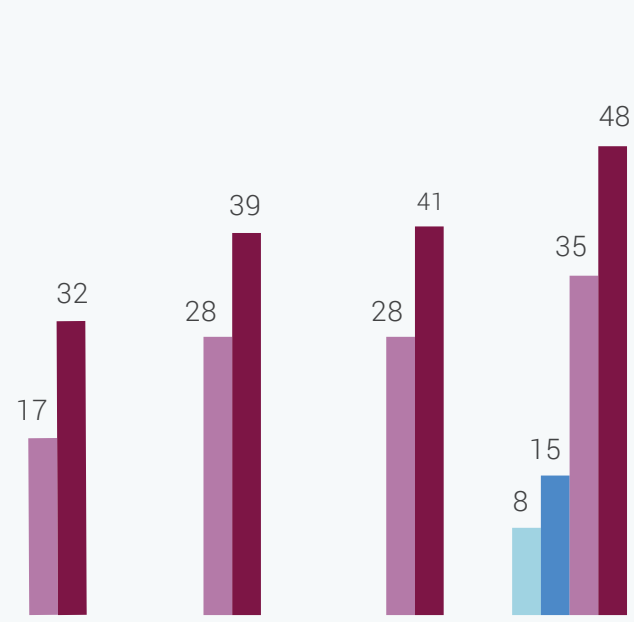

2012

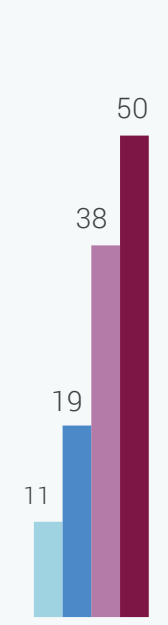

2016

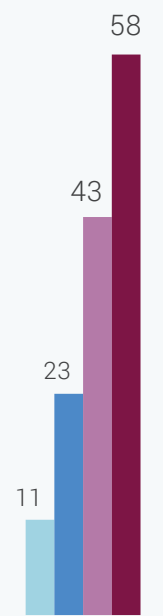

2017

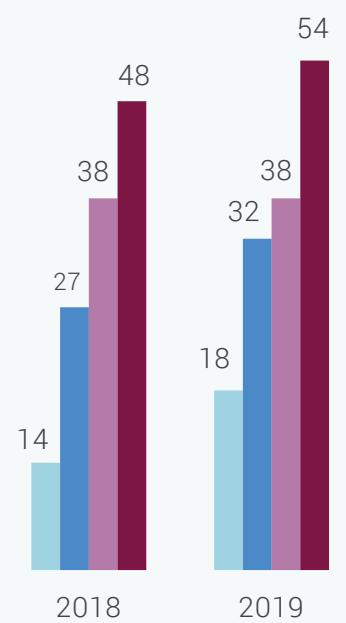

Water - Total Respondents 


\section{SNAPSHOT}

\section{CLIMATE CHANGE / TURKEY 2019}

\section{Response \& Scoring Summary \\ Number of companies included in the analysis

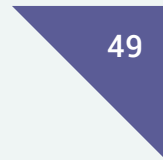

Number of responding companies (BIST-100 only)

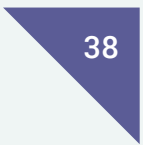

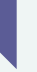

Number of companies scoring above management level

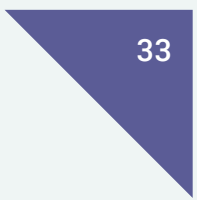

Number of public responses

\section{Governance \& Strategy}

Climate-related issues integrated into business strategy impac

Climate risks and
opportunities have impacted the business

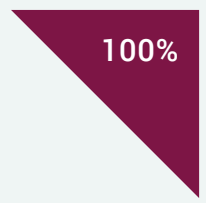

Provide incentives for the management of climate-related issues

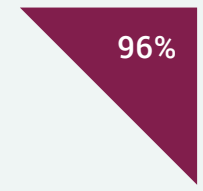

Use climate-related scenario analysis to inform organization's business strategy

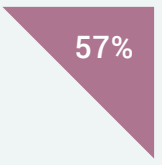

Board-level oversight of climate-related issues within the organization

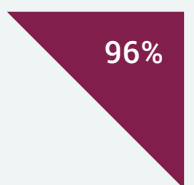

Risks \& Opportunities

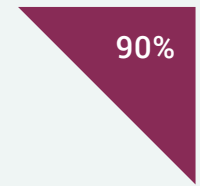

Risks and opportunities have factored into organization's financial planning process

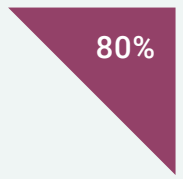
with the potential to

have a substantive financial or strategic impact on the business

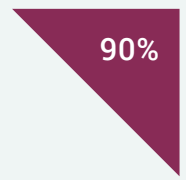

Total number of risks identified as relevant
Identified any inherent Reported decrease in climate-related risks Scope 1 \& 2 emissions
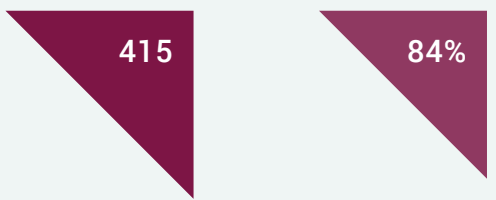

Total number of opportunities identified

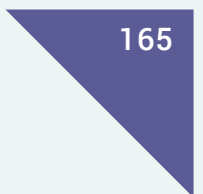

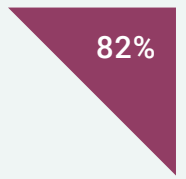

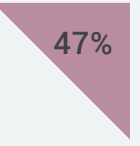

Targets \& Performance

Provide products and/or services that enable a third party to avoid GHG emissions

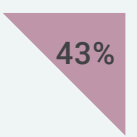

Have emissions reduction initiatives that were active within the reporting year

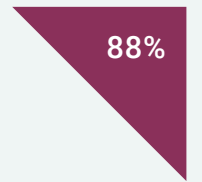

Reported Scope 3 emissions

Provide products and/or services that

are classified as low-carbon products

\section{$39 \%$}

Climate Change Management

Use an internal price on carbon

Developed a low-carbon transition plan to support the long-term business strategy

$16 \%$

Have no Science Based Target yet but anticipate setting one

in the next 2 years

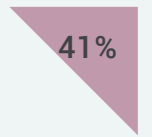

Reporting engagement with the value chain on climate-related issues

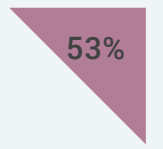

Published voluntary sustainability report 


Response Summary
\& Current State
$\begin{gathered}\text { Number of } \\ \text { companies included } \\ \text { in the analysis }\end{gathered}$

Number of public responses

\section{5}

Engage with the value chain on water-related issues

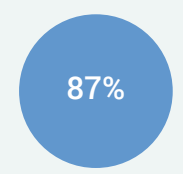

Water quality \& quantity are vital for the success of the business

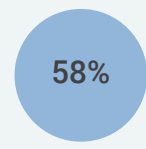

Water aspects of all operations $(100 \%$ of sites/facilities/operati ons) are regularly

measured and monitored

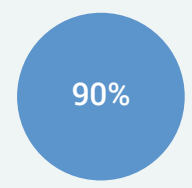

\section{Business Impacts \\ $\&$ Procedures}

\section{Organization has experienced detrimental} water-related impacts

\section{$32 \%$}

Identified flooding as the top impact driver of the water-related detrimental impacts

\section{$16 \%$}

Undertook a water-related risk assessment

$94 \%$

$13 \%$

Both direct operations and supply chain have integrated in the procedures for identifying and

assessing water-related risks

Employers are the most considered stakeholders in organization's water-related risk assessments

$48 \%$

\section{Governance \& Strategy}

Reported board-level oversight of water-related issues within the organization

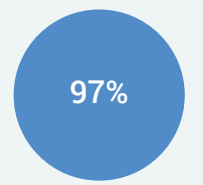

Reported engagement in activities that could influence public policy on water

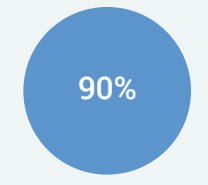

The board chair has the responsibility for water-related issues

Water-related issues are integrated into the long-term (more than 10 years) strategic business plan

$48 \%$

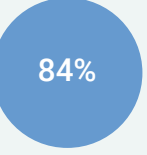

Identified risks in the direct operations with the potential to have impact on the business within a year

$19 \%$

Identified cost savings as the most primary water-related opportunity

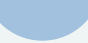

Water-related issues are integrated into financial planning of the organization

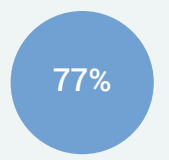

Reported that more than $50 \%$ of company's total global revenue could be affected by water risks

\section{Accounting}

Targets \& Strategy
Total water withdrawal by source is higher than the previous reporting year

\section{$29 \%$}

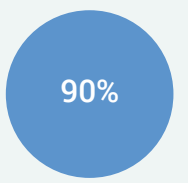

Total water discharge by destination is lower than the previous reporting year

$55 \%$

More than $50 \%$ of total water use is recycled and reused

$13 \%$

More than $50 \%$ of suppliers have requested to report on their water use, risks and/or management information

\section{$19 \%$}

Company-wide targets and goals are in place

Reduced environmental impacts reported as the most common primary motivation behind water targets

\section{$58 \%$}

More than $50 \%$ of targets are achieved

$71 \%$

Water stewardship is the top motivation behind the water goals

Water withdrawal data has been externally verified

Identified any linkages or trade-offs between water and other environmental issues 


\section{KEY FINDINGS CLIMATE CHANGE / TURKEY 2019}

The content of CDP responses has improved markedly for respondents in Turkey. The total number of companies to receive an $A$ or $A$ - is five now (three in 2018). Number of companies receive a B or B-is 28 (22 in 2018) in total. In the same manner, the number of companies receiving a $C$ or $D$ decreased.

There has been a steady increase in the completeness of submissions (responding more than $75 \%$ of questionnaire) by disclosing companies. 98 percent of submissions were in the most 'complete' quartile this year suggesting that almost all companies have already recognized the value of comprehensive disclosure through CDP.

Although all companies in Turkey stated that they have integrated climate change into their business strategy, the amount of companies conducting climate change scenario analysis to understand strategic implications of climaterelated risks and opportunities (57\%) suggests that there is still a room for improvement.

Only $37 \%$ of responding companies scheduled climaterelated issues as an agenda item in all strategy meetings. In those meetings, the most common discussed governance mechanisms related to business strategy is monitoring and overseeing progress against goals and targets for addressing climate-related issues.

Companies in Turkey have been reluctant to engage in advanced climate related initiatives such as setting up Science Based Targets, putting a price on carbon or setting renewable energy targets. Only $10 \%$ ( $7 \%$ in 2018 ) of respondents consider that their target is a science-based target, but these targets have not been approved as sciencebased by the Science Based Targets Initiative (SBTi). The rate of companies in Turkey that use an internal carbon price is $27 \%$ (18\% in 2018$)$. Besides, only $10 \%$ of respondents have set a renewable energy consumption target.

The risk perception of climate change is quite high, while a large number of companies are also showing an understanding of the business opportunities presented by climate action. Almost all responding companies ( $90 \%)$ identified inherent climate-related risks with the potential to have a substantive financial or strategic impact on the business, which is higher than the companies identified potential opportunities (78\%)

The percentage of transition risks in the direct operations $(73 \%)$ and in value chain (49\%) are slightly higher than the physical risks ( $71 \%$ and $41 \%$ accordingly). Those that identify transition risks focus on potential policy and legal changes, with the most frequently reported risk being the increased operating costs.
Most companies in Turkey understand that they need to safeguard their reputations through effective climate change management and communication of their climate change strategy. Therefore, the most commonly reported risk type considered in the companies' climate-related risk assessments is related to reputation (94\%). Increased pricing of GHG emissions is a newly added risk type in CDP's questionnaire and $39 \%$ of companies already identified it as a risk. This is attributable to the recent international developments on carbon markets, especially discussions over Article 6 of Paris Agreement.

The frequency and time horizon for risk assessment is also key to business resilience into a business. Most (80\%) Turkish companies assess the risks in every six months or even more frequently and $14 \%$ of companies assess risks annually. Further $70 \%$ consider risks for more than six years into the future with a long-term vision.

Since 2018, companies were directly asked to report the potential financial impact figures of the risks they disclosed as a key data point in CDP's scoring methodology. 65 percent of companies provided at least one figure for the potential financial impact of risks and $59 \%$ for the potential financial impact of opportunities. These companies are leading the pack in this developing area of disclosure.

The most frequently considered opportunity types in the organization's climate-related risk assessments are linked to new products and services (63\%) affecting both the customer and direct operational parts of the supply chain. Resource efficiencies and alternative energy sources (43\%) are the next most frequently identified money savers.

88 percent of companies in Turkey report active emissions reduction initiatives in the reporting year. More than half of companies $(53 \%)$ reported that the initiatives are related to energy efficiency processes. By improving their energy efficiency, companies reduce costs.

Energy-related activities represent the most significant GHG emission sources. Almost all companies (96\%) in Turkey provides energy consumption totals including energy consumption totals from renewable sources (41\%). In the reporting year, responding companies in Turkey consumed 49 Terra Watt hours (TWh) electricity in their operations of which 4.5 TWh came from renewable energy sources.

There are differences between CDP responses and the level of information companies disclose in other channels. Even though $84 \%$ of companies published information about organization's response to climate change for this reporting year in places other than CDP response, only $59 \%$ (52\% in 2018$)$ published voluntary sustainability report. 


\section{KEY FINDINGS \\ WATER SECURITY / TURKEY 2019}

A significant portion of responding companies (94\%) reporting via CDP now measure and monitor more than $50 \%$ of all water aspects across all operations but only $45 \%$ require their key suppliers to report water use, risk, and management.

While $48 \%$ (27\% in 2018$)$ of responding companies have measured that, their water consumption is lower than the previous year, $26 \%(27 \%$ in 2018$)$ of the companies report an increase. In terms of water withdrawals, $52 \%$ (38\% in 2018) of responding companies report a decrease, while $26 \%$ (35\% in 2018) measured an increase compared to previous year.

39 percent of companies reported that more than $50 \%$ of total withdrawals sourced from water stressed areas. Moreover, most of the water withdrawal is sourced from third party sources $(71 \%)$ and most of the water is discharged to third party destinations (81\%) which shows water crosses the company boundary, at either the corporate level or facility level.

There are financial risks that companies face from water issues. 32 percent of companies in Turkey suffering from some sort of water-related issue (experienced detrimental impacts) over the reporting period- mostly related to flooding or droughts.

87 percent of responding companies engage with the value chain on water-related issues and $45 \%$ ask their suppliers to report on their water use, risks, and/or management information.

V 94 percent of responding companies state that water risks are assessed. However, water-exposed companies should conduct risk assessments that are company-wide and comprehensive, including their direct operations and their supply chains. 35 percent of disclosing companies meet this higher standard.

Water is a local issue. Therefore $65 \%$ of companies in Turkey conduct risk assessment which took place at the river basin level up from $58 \%$ in 2018 - and $90 \%$ of responding companies factor local communities into their water risk assessments.

By improving their understanding of the way in which water is managed around them, companies are better prepared to respond proactively to challenges. 48 percent of responding companies identified inherent water-related risks with the potential to have a substantive financial or strategic impact on the business both in direct operations and in the rest of our value chain.

Physical risks are the most reported types of risks in the direct operations ( $77 \%$ ) and in the value chain (42\%). Increased operating costs are the most reported potential impact (45\%) of identified risks in the direct operations; in the value chain the most reported risk drivers are drought (13\%) and flooding (13\%).

In most parts of the world, water is cheap, with users often paying below-cost rates for their water supply. Only $16 \%$ of responding companies in Turkey cite higher water prices as a potential risk, either in their direct operations or along their supply chain.

There are also positive opportunities identified from taking action on water issues. 87 percent of responding companies identified water-related opportunities with the potential to have a substantive financial or strategic impact on the business. Efficiency (71\%) and markets (45\%) are the most reported types of opportunities currently being realized.

Although companies report high levels of risk exposure and board-level oversight, they have not yet tied water issues to performance. 97 percent of companies report that they have boardlevel oversight of water-related issues within the organization. In more than half of the responding companies (52\%), CEO is the one with responsibility for water-related issues but only $58 \%$ have incentives in place for C-Suite executives on water-related issues.

74 percent of respondents use climate-related scenario analysis to inform its business strategy. Only $19 \%$ (12\% in 2018) of companies use an internal price on water which is lower than the companies that use an internal carbon price in Turkey (27\%).

Looking at the longer term $90 \%$ of respondents in Turkey are integrating water-related issues into organization's long-term strategic business plan. A further $48 \%$ integrated those issues into strategic business plan for more than 10 years.

Most of the companies ( $90 \%$ ) have set company-wide targets and goals in place to better manage water risks. 71 percent of responding companies achieved more than $50 \%$ of their water targets. This is a substantial increase from last year, which was $42 \%$. The percentage of respondents that provide quantitative metric for water targets is $94 \%$. A further $74 \%$ provide description of water goals.

V 84 percent of responding companies identified linkages or tradeoffs between water and other environmental issues in the direct operations and/or other parts of the value chain. Increased energy use is the most common reported type of trade-off (29\%) and as expected, decreased energy use is the most common reported type of linkage (26\%). 


\section{COMPANY RESPONSE SUMMARY CLIMATE CHANGE / TURKEY 2019}

\section{CARBON PRICING}

Carbon pricing has emerged as a key policy mechanism to drive greenhouse gas emissions reductions and mitigate the dangerous impacts of climate change. As the number of jurisdictions with carbon pricing policies has doubled over the last decade, CDP data users are interested in understanding how companies are affected by these schemes. This module examines details on the operations or activities regulated by carbon pricing systems, carbon credits and internal prices on carbon.

\section{$\mathbf{2 6 \%}$ use an internal price on carbon}

\section{GOVERNANCE}

This module is intended to capture the governance structure of the company with regard to climate change and provides data users with an understanding of the organization's approach to climate-related issues at the board-level and below board-level. Responding companies in Turkey have strong governance structures and strategies for climate change. This is reflected in percentages associated with questions on senior level responsibility, providing incentives for the management of climate-related issues, and having a climate risk management procedure in place.

v $\mathbf{9 6 \%}$ have board-level oversight of climate-related issues within the organization

- $\mathbf{9 2} \%$ have climate risk management procedures in place

- $\mathbf{9 6 \%}$ provide incentives for the management of climate-related issues

\section{EMISSIONS}

A meaningful and consistent comparison of emissions over time is an essential step in environmental reporting. This module allows companies to provide the base year and base year emissions and provide details of the standard, protocol, or methodology used to collect activity data and calculate Scope 1 and Scope 2 emissions. Reporting emissions is best practice and a pre-requisite to understanding and reducing negative environmental impacts.

\ $\mathbf{9 2} \%$ reported Scope $1 \& 2$ emissions

- $\mathbf{4 9} \%$ reported a decrease in Scope 1 \& 2 emissions

- $\mathbf{4 7 \%}$ reported an increase in Scope 1 \& 2 emissions

\section{ENGAGEMENT}

In order to truly reduce global emissions, companies must engage with their value chain on climate-related issues. Questions in this module examine how organizations are working with their suppliers, customers and other partners. This module provides data users with insight into the different types of activities in which organizations engage to influence public policy on climate-related issues.

V $\mathbf{5 9 \%}$ published voluntary sustainability report

च $22 \%$ reported engagement with more than $50 \%$ of suppliers

v $\mathbf{5 3} \%$ reported engagement with the value chain in climate-related issues

\section{TARGETS}

Target setting provides direction and structure to environmental strategy. Questions in this module focus on emission targets, additional climate-related targets, details on emission reduction initiatives and low-carbon products. Providing information on quantitative targets and qualitative goals, and progress made against these targets, can demonstrate organization's commitment to improving climate-related issues management at a corporate level.

च $\mathbf{8 8} \%$ have an emission target that was active in the reporting year

- $\mathbf{8 8} \%$ have an emission reduction initiatives that were active within the reporting year

V $41 \%$ reported anticipation of setting science-based targets in the next 2 years 


\section{ENERGY}

Energy related activities represent the most significant GHG emission sources. This energy module of CDP Climate Change Questionnaire provides transparency on the consumption and generation of energy by organizations. Accurate emissions accounting depends on a comprehensive account of energy. It is expected that organizations have already collected the necessary energy data for the disclosure of emissions in previous modules.

- $\mathbf{4 1} \%$ have energy consumption totals from renewable sources (excluding feedstocks) in MWh. >0

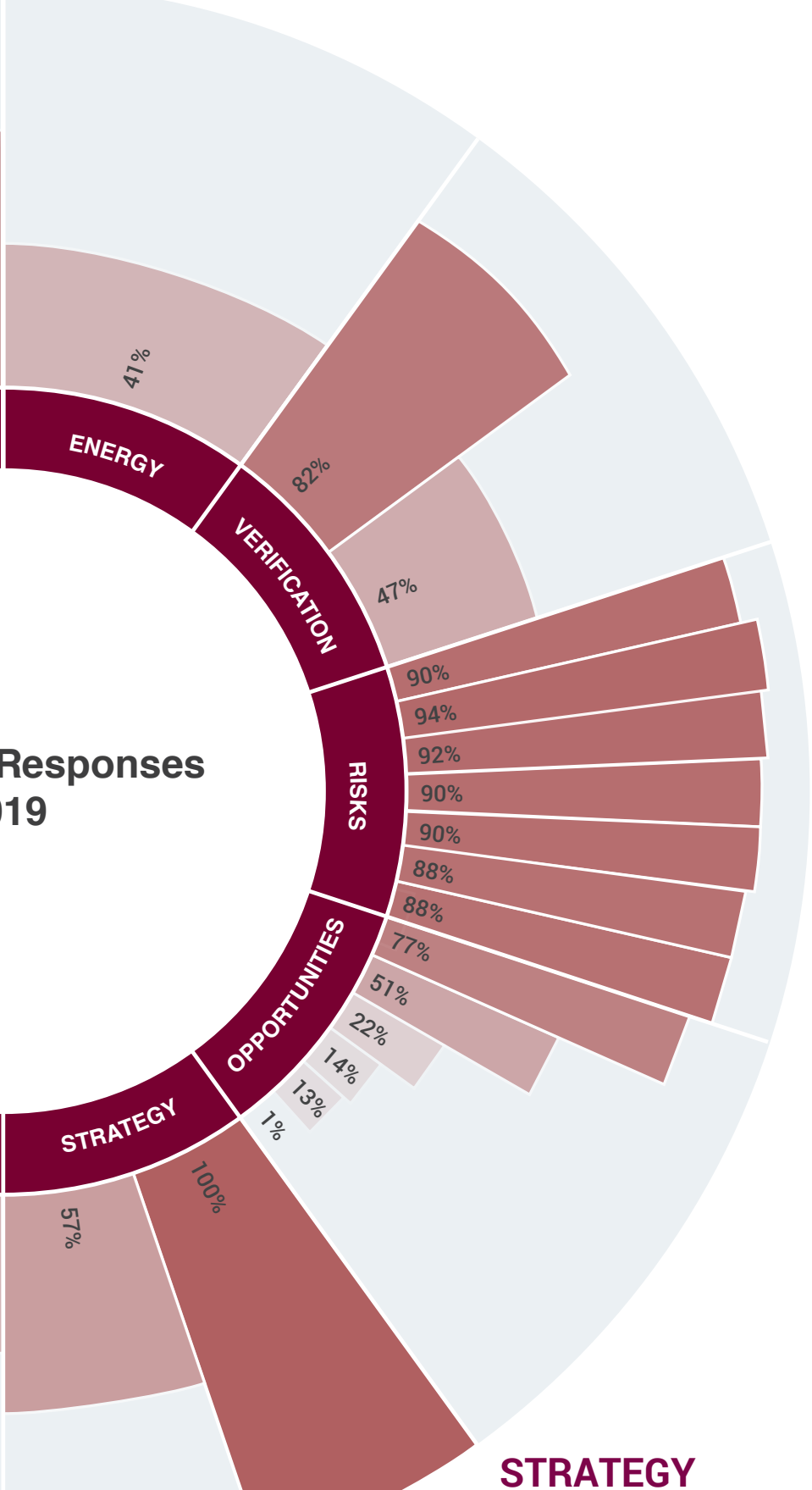

\section{VERIFICATION}

Verification and assurance are good practices in environmental reporting as they ensure the quality of data and processes disclosed. This module requests details on the verification status that applies to organizations' reported Scope 1,2 and 3 emissions, as well as on the verification of other climate-related information reported in the CDP disclosure.

Third-party verification or assurance process in place;

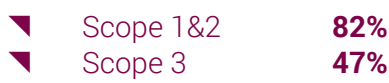

\section{RISKS}

Evaluating exposure to climate-related risks and opportunities over a range of time horizons allows for a strategy for the transition to a low-carbon economy recognized in the Paris Agreement and UN SDGs. This module focuses on processes for identifying, assessing, and managing climate-related issues as well as on the climate-related risks identified by the organization. Responding Turkish companies appear particularly mindful of the reputational and regulation risks posed by climate change.

$\mathbf{9 0} \%$ identified any inherent climate-related risks with the potential to have a substantive financial or strategic impact on the business.

Mostly reported risk types considered in the organization's climate-related risk assessments:

$\begin{array}{lll}\text { Reputation } & \mathbf{9 4 \%} \\ & \text { Acute physical } & \mathbf{9 2 \%} \\ & \mathbf{9 0 \%} \\ & \text { Market } & \mathbf{9 0 \%} \\ & \text { Technology } & \mathbf{8 8 \%} \\ & \text { Current regulation } & \mathbf{8 8 \%}\end{array}$

\section{OPPORTUNITIES}

Besides many of the challenges that companies face, climate change also presents opportunities. Among the companies that responded to opportunities module in 2019, products \& services and resource efficiency appear as the mostly reported opportunity types considered in the organization's climate-related risk assessments.

v $\mathbf{7 7 \%}$ identified any inherent climate-related opportunities with the potential to have a substantive financial or strategic impact on the business.

\section{Mostly reported opportunity types considered in the} organization's climate-related risk assessments:

$\begin{array}{lll}\nabla & \text { Products and services } & \mathbf{5 1 \%} \\ & \text { Resource efficiency } & \mathbf{2 2 \%} \\ & \text { Markets } & \mathbf{1 4 \%} \\ & \text { Energy source } & \mathbf{1 3 \%} \\ & \text { Resilience } & \mathbf{1 \%}\end{array}$

CDP data users are interested in organizations' forward looking strategies and financial decisions that are driven by climate-related future market opportunities, public policy objectives, and corporate responsibilities. This module allows organizations to disclose whether they have acted upon integrating climate-related issues in to their business strategy. The module also includes questions on scenario analysis and transition planning which are important evolutions in strategic environmental planning. 


\section{COMPANY RESPONSE OVERVIEW}

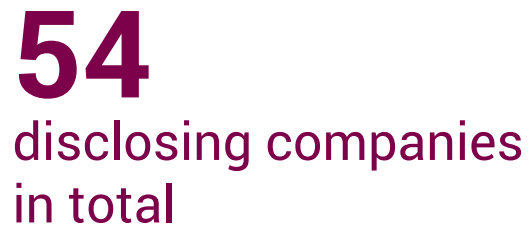

Disclosure of environmental risk and impact is a critical first step for insight and action on climate change. CDP's sector specific questionnaires provide companies with a guide to transition to a sustainable business, helping companies find clear, measurable Key Performance Indicators (KPIs) to work towards and report on which leads to a better overall performance. Besides, investors use this comparable information to better inform their engagement and investment decisions and ultimately protect their investments.

CDP requests information on climate risks and low-carbon opportunities from the world's largest companies on behalf of over $\mathbf{5 2 5}$ institutional investor signatories with combined assets of US\$96 trillion under management. Globally $\mathbf{8 3 6 0}$ companies disclosed to CDP Climate Change program in 2019.

CDP requested the constituent companies of Borsa Istanbul 100 Index (BIST-100) and companies with high environmental impact in Turkey to disclose their environmental information in 2019. In total, 54 companies responded to CDP Climate Change Program in Turkey up from 48 companies (13\% increase) in 2018. Out of 54 companies, 38 are from the official sample (BIST-100) and 16 are companies outside the official sample that report without being invited by the investors as self-selected companies
(SSCs) or companies that are listed in CDP's global environmental samples. The following analysis in this report includes 49 companies in total, excluding the companies responded as See Another (SA) which means that the company is a subsidiary of a parent company which responds to CDP.

CDP Turkey 2019 Climate Change analysis presents the progress made by responding companies in reducing emissions, responding to climate-related risks and opportunities, and also climate change management. Overall, companies in Turkey performed well in high-level management responsibility for climate change and emissions reporting. When compared to global CDP results however; there is a significant room for improvement for companies in setting science-based targets and internal carbon pricing.

The figure below represents the disclosure levels of companies. It is a calculation of the extent to which the full questionnaire was answered. There has been a steady increase in the completeness of submissions (responding more than $75 \%$ of questionnaire) by disclosing companies. 98 percent of submissions were in the most 'complete' quartile this year suggesting that almost all companies have already recognized the value of comprehensive disclosure through CDP.

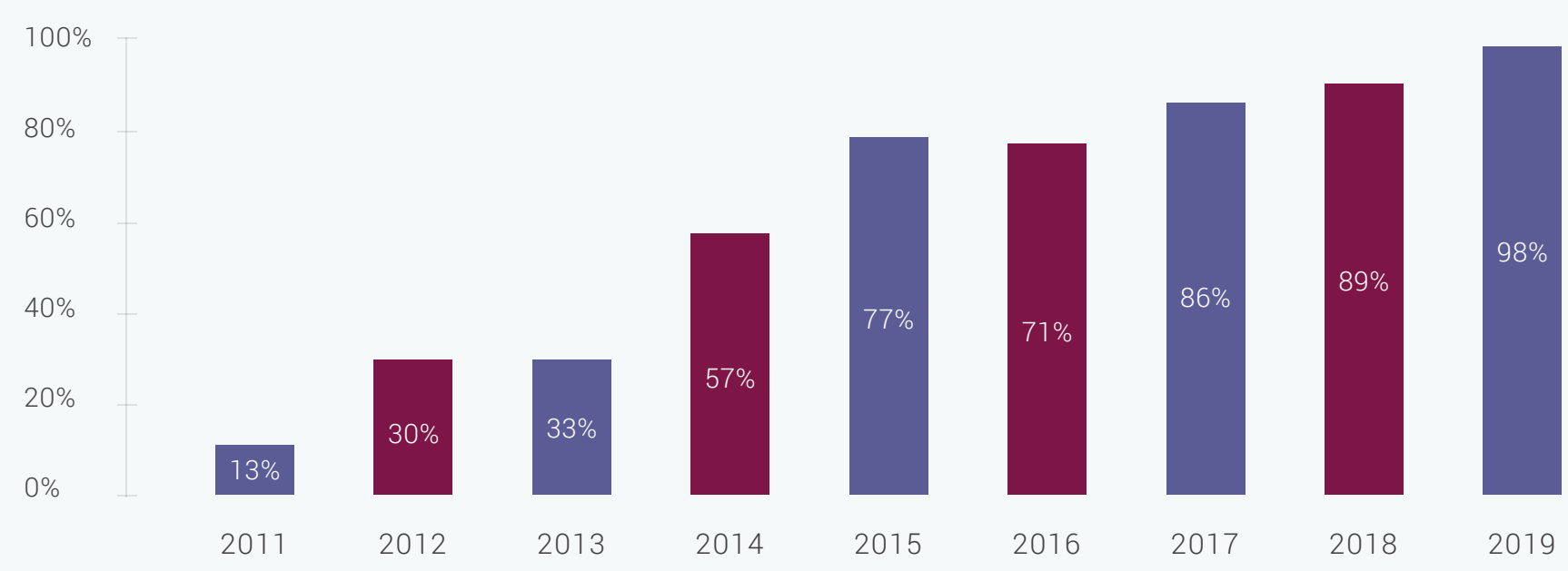




\section{$96 \%$}

have board-level oversight of climaterelated issues

\section{$90 \%$}

provide monetary

rewards for the

management of climaterelated issues

\section{$100 \%$}

integrated climate
change into business
strategy

\section{$57 \%$}

deploying climate-related scenario analysis for business strategy

Albaraka Turk's scenario analysis is based on International Energy Agency (IEA) Sustainable Development

Scenario. The company prefer to use this scenario because they strongly opt for the commitments to meet criteria set by the Paris Agreement as well as using TCFD by 2024 for climate related risk disclosure.
V How to manage climate change? Governance \& Business Strategy

Climate change is now an issue at the very top of corporate decision making as companies face increasing financial and reputational risks from climate change, deforestation, and water security. Boardlevel oversight of climate-related issues is considered best practice and provides an indication of the importance of climaterelated issues to the organization. On climate matters, almost all respondents (96\%) stated that they have board-level oversight of climate-related issues within the organization; almost half (49\%) of the companies have CEO oversight.

Top management teams have integrated climate-related concerns in performance evaluation of key personnel. 96 percent of responding companies provide incentives for the management of climate-related issues, including the attainment of targets. 90 percent ( $84 \%$ in 2018 ) of the companies have monetary incentives.

For the first time in CDP's history in Turkey, all responding companies report that climate change is integrated into their business strategy. 37 percent of companies scheduled climate-related issues as an agenda item in strategy meetings. The most common governance mechanisms used by Turkish companies that have integrated climate issues in their business strategy are:

- Monitoring and overseeing progress against goals and targets for addressing climaterelated issues;

- Monitoring implementation and performance of objectives;

- Overseeing major capital expenditures, acquisitions and divestitures;

- Reviewing and guiding annual budgets, business plans, major plans of action; risk management policies and strategy.

Task Force for Climate-related Financial Disclosures (TCFD) recommends the application of internal carbon price as a key metric in scenario analysis because it is forward-looking and can help companies manage climate-related risks and opportunities. Companies can also use internal carbon price as a tool to create funds to invest in low carbon transition.

Given the importance of forward-looking assessments of climate-related risks and opportunities, scenario analysis is an important and useful tool for an organization to use, both for understanding strategic implications of climate-related risks and opportunities, and for informing stakeholders of how the organization is positioning itself in recognition of these issues. 57 percent claim to be implementing current best practice by using a scenario-based approach to inform their corporate strategy around climate change, while an additional $31 \%$ anticipate that they will introduce this over the next two years. 


\section{COMPANY RESPONSE OVERVIEW}

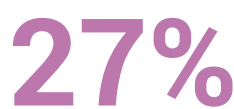

\section{use an internal carbon price}

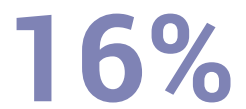

\section{have developed a low- carbon transition plan to support the long-term business strategy}

ENKA has updated its methodology to focus on low-carbon businesses and investments through constructing new buildings according to green building standards, focusing on power plant rehabilitation projects and new investments in turbine parts.
Most commonly, companies use internal carbon price as a tool to reveal potential opportunities that may emerge in the transition to the low-carbon economy. The number of companies embedding an internal carbon price into their business strategies has been increasing globally which is largely driven by the development of regulations that directly or indirectly price carbon and the increasing pressure from shareholders and customers on companies to adequately manage their climate-related risks. Expectedly, the rate of companies in Turkey that use an internal carbon price has also increased from $18 \%$ to $27 \%$ compare to previous year. A further $33 \%$ plan to implement a price on carbon in the next two years. Out of 13 companies using an internal carbon price, three of them use an implicit carbon price; six use a shadow price, two use an internal fee and four companies use offsets.

16 percent $(11 \%$ in 2018$)$ of responding companies have developed a lowcarbon transition plan to support the long-term business strategy. A further $20 \%$ plan to complete it within the next two years.

\section{Implicit Carbon Price}

Arçelik has an implicit price system on plants. Every plant has its own budget about Energy Efficiency Improvement Projects. Thanks to these 'Efficiency Improvement Projects', GHG emissions can be reduced while efficiency improvement projects are developed. At the end of each year, total investment of energy projects is divided by total $\mathrm{CO} 2$ reduction; hereby calculating the price to be applied.

\section{Shadow Price}

Internal carbon pricing is allowing energy management and planning teams to calculate the cost of the CO2 impacts of Migros Ticaret's operations. Accordingly, the company takes into account the cost of carbon when planning budgets and building business cases for gas and electricity reduction initiatives across the business.

Percentage of companies that use an internal price on carbon

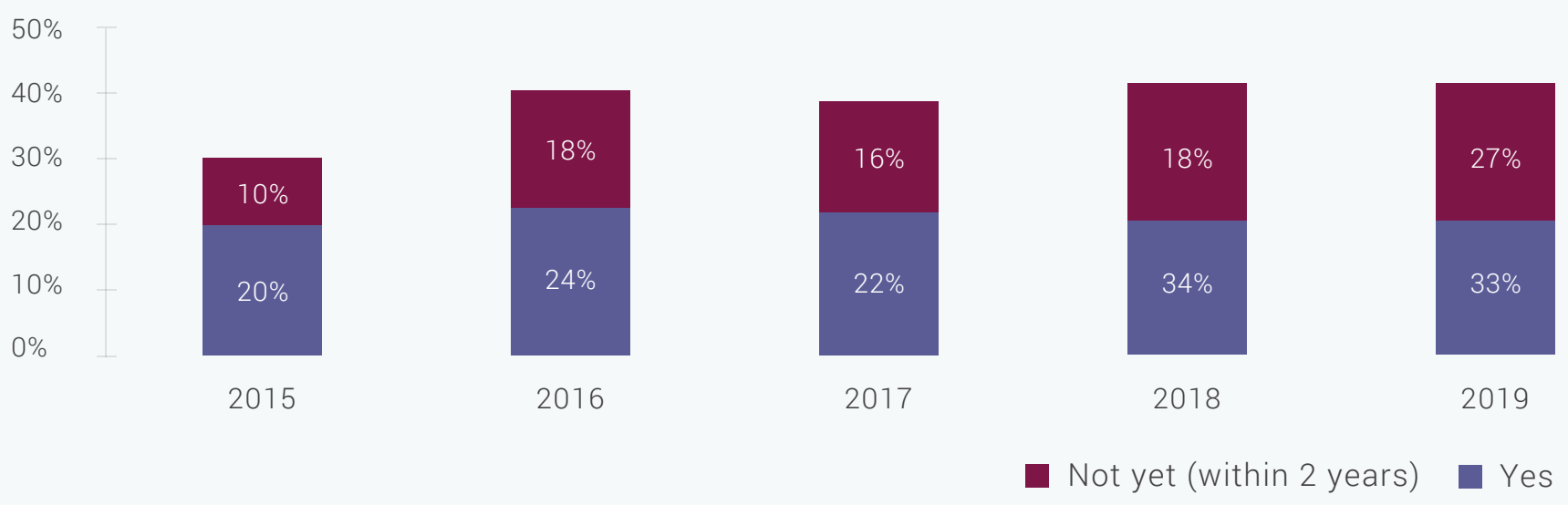




\section{$80 \%$}

\section{have factored risks and opportunities into financial planning process}

\section{5 \\ total number of risks identified}

\section{Visk Assessment \& Opportunities}

CDP questionnaire is asking for more detail beyond looking at current performance to grow pressure on companies to better evaluate the financial opportunities and risks they face in the transition to a sustainable economy. 90 percent of responding companies reported that climate risks have impacted their business. Furthermore, $80 \%$ of companies have factored risks and opportunities into company's financial planning process.

Most of the responding companies (90\%) identified inherent climate-related risks with the potential to have a substantive financial or strategic impact on the business. The potential financial impact of risks identified by companies in Turkey amounts to US\$8 billion in total. Total number of risks identified as relevant is 415 (357 in 2018).

Increasingly more companies in Turkey understand that they need to safeguard their reputations through effective climate change management and communication of their climate change strategy. Therefore, the most commonly reported risk type considered in the companies' climate-related risk assessments is related to reputation (94\%). Increased pricing of GHG emissions is a newly added risk type in CDP's questionnaire and $39 \%$ of companies already identified it as a risk. This is attributable to the recent international developments on carbon markets, especially discussions over Article 6 of Paris Agreement'

Acute or increased severity of climate change $(51 \%)$ and changes in precipitation (43\%) are the most commonly reported primary climate risk drivers. It is attributable to the recent temperature changes and extreme weather conditions, which affect almost all companies in Turkey.

Transition risks are related to society's response to climate change, such as policy and regulatory changes, the development of new technologies and business models, or changing consumer demand. Physical risks, on the other hand, are related to changing climate and extreme weather conditions, which can disrupt company operations and supply chains. The percentage of transition risks in the direct operations (73\%) and in value chain (49\%) are slightly higher than the physical risks ( $71 \%$ and $41 \%$ accordingly) for responding companies in Turkey.

Approximately $27 \%$ (25\% globally in 2018) of the companies who identified substantive transition risks focused only on potential policy and legal risks related to climate change and did not identify climate-related market, reputation, or technology risks as substantive. In addition, most companies (88\%) are identifying potential physical and transition risks that would affect their direct operations.
Brisa relies on energy to continue its business, prices of which are rising rapidly due to both transitional aspects as well as physical events related disruption. Energy security is one of the most strategic aspects Brisa and considered as a part of their mid to long-term business plan in terms of risks around access to sufficient and clean energy sources as well as the risk of steep increases in energy prices.

${ }^{1}$ Article 6 of Paris Agreement relates to carbon markets by providing an accounting framework for international cooperation and international transfer of carbon credits as well as establishing a work program for non-market approaches such as carbon taxing. 
Turkey signed Paris Agreement together with other participant countries in 2016 and is expected to join Emission Trading Schemes (ETS) as a candidate company for the EU in future. However, according to Coca Cola İçecek, uncertainties exist concerning the scope and the requirements of ETS and national commitments on Paris Agreement. The Ministry of Energy and Natural Resources and Ministry of Environment have announced their policy on energy and carbon markets toward 2020, but the timeframe has not been shared yet. It is not very clear when ETS Directive and national commitments will come into force in Turkey. It may have an impact on Cola Cola İçecek's cold drink equipment procurement process. Turkey has committed to reduce emissions by $21 \%$ according to its Nationally Determined Commitment (NDC). During their operations, factories emit GHG due to stationary and mobile combustion, fugitive gases, use of electricity and scope 3 activities. Therefore, cap and trade schemes/carbon tax will have a potential financial impact on the Company.
Due to the global complexity of supply chains today, a disruption in one part of the world can have significant impacts elsewhere. Therefore, both investors and companies should take note of these dynamics and broaden their climate risk assessment practices if they are to remain profitable in the future.

Since 2018 , companies were directly asked to report the potential financial impact figures of the risks they disclosed as a key data point in CDP's scoring methodology. 65 percent of companies provided at least one figure for the potential financial impact of risks and $59 \%$ for the potential financial impact of opportunities. These companies are leading the pack in this developing area of disclosure.

\section{The top two identified causes of financial} impact are increased operating costs (76\%) that are often linked to GHG emissions pricing; and reduced revenue from decreased production capacity $(82 \%)$ due to the physical impacts of climate change.

\section{The frequency and time horizon for risk} assessment is also key to business resilience into a business. Most (80\%) Turkish companies assess the risks every six months or even more frequently and $14 \%$ of responding companies assess risks annually. Further $70 \%$ consider risks for more than six years into the future with a long-term vision.

Responding companies recognize opportunities as well as risks posed by climate change. 78 percent of all reporting companies identified potential opportunities that could have a substantive or strategic impact on their business. However, this number was much higher last year (95\%).

Therefore, the proportion of companies that has identified risks (90\%) resulting from climate change is larger than the share of companies that has identified positive opportunities. Total number of opportunities identified as relevant is 165 (153 in 2018)

The majority of these opportunity types considered in the organization's climaterelated risk assessments are linked to new products and services (63\%) affecting both the customer and the direct operations of the supply chain. Resource efficiencies and alternative energy sources $(43 \%)$ are the next most frequently identified money savers. Besides, shift in consumer preferences (39\%) and development and/ or expansion of low emission goods \& services (33\%) are most commonly reported primary climate-related opportunity drivers.

Percentage of companies seeing at least one risk of the respective type in the respective horizon

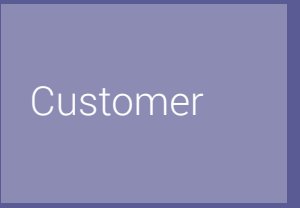

Supply Chain
Direct
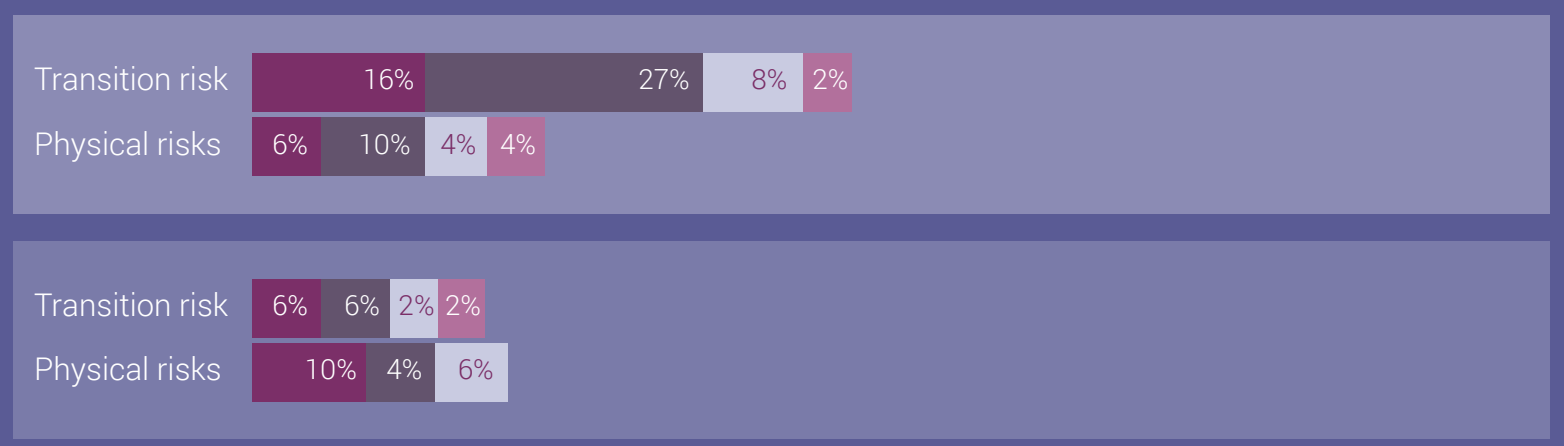

\begin{tabular}{|l|l|l|l|l|l|}
\hline Transition risk & $20 \%$ & $55 \%$ & & \\
\hline Physical risks & $20 \%$ & $31 \%$ & $29 \%$ & $6 \%$ \\
\hline
\end{tabular}


Top 5 primary climate risk drivers and climate-related opportunity drivers

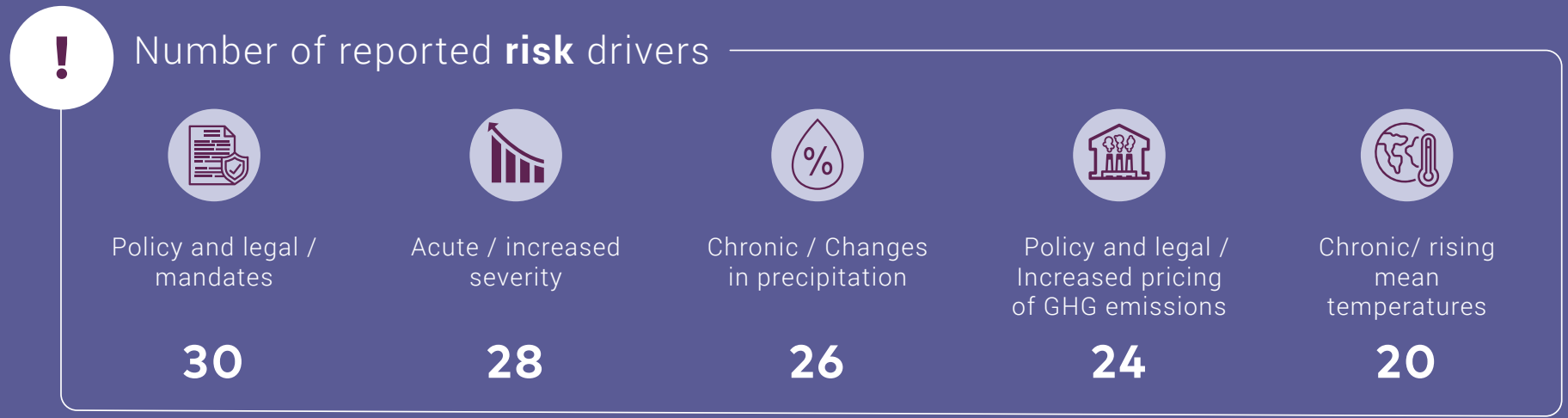

$+_{+}$Number of reported opportunity drivers

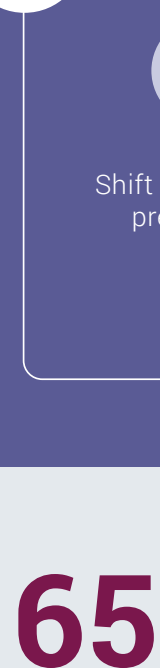

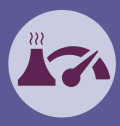

Development and / or expansion of low emission goods and services

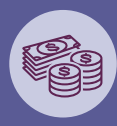

Access to new markets

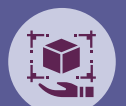

Development of new products or services through R\&D and innovation

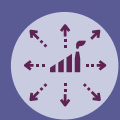

Use of more efficient production and distribution processes

\section{5
total number of
opportunities \\ 165
total number
opportunities identified}

The Renewable Energy Law offers incentives for renewable energy investments through a new feed-in tariff policy for the next ten years and offering additional incentives for using locally manufactured equipment. The guarantee price for wind power plants are 7.3 USD cent/ kwh and according to Zorlu Enerji this will be an opportunity in case of development of decentralized electricity production.
Percentage of companies providing details on substantive risks

\section{(. $90 \%$}

Identified being exposed to substantive risks

\section{(กิ11 $71 \%$}

Provided potential financial impact figures
Percentage of companies providing details on substantive opportunities

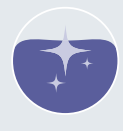

\section{$78 \%$}

Identified being exposed to substantive opportunities

\section{$61 \%$}

Provided potential financial impact figures

\section{$78 \%$}

identified both risks and opportunities which could have a substantial impact

Climate change poses an opportunity for Aselsan to develop more lowemissions goods and services. This would likely affect the projected revenue in the future since Aselsan aims to be one of the main producers of renewable energy technologies in Turkey. Due to emerging opportunities to develop low-emission goods and services, the investment in R\&D projects will continue. The total expenditure on R\&D activities was 2163 million TRY, the previous year was 1675 million TRY. In 2019, ASELSAN actively followed a policy that would ensure maximum efficiency and profitability while seizing new opportunities offered by the latest technologies. 
Where does the risk factor and opportunity occur in the value chain? (percentage of companies)

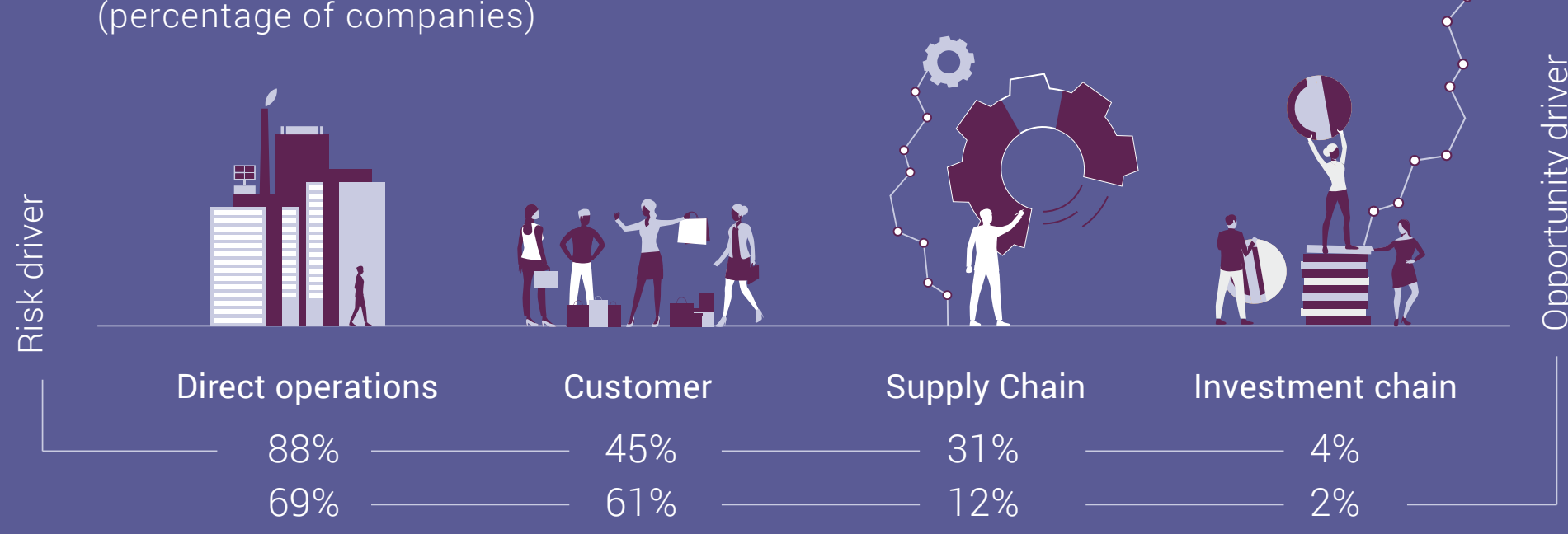

Most commonly reported risk \& opportunity types by responding companies (percentage of companies)

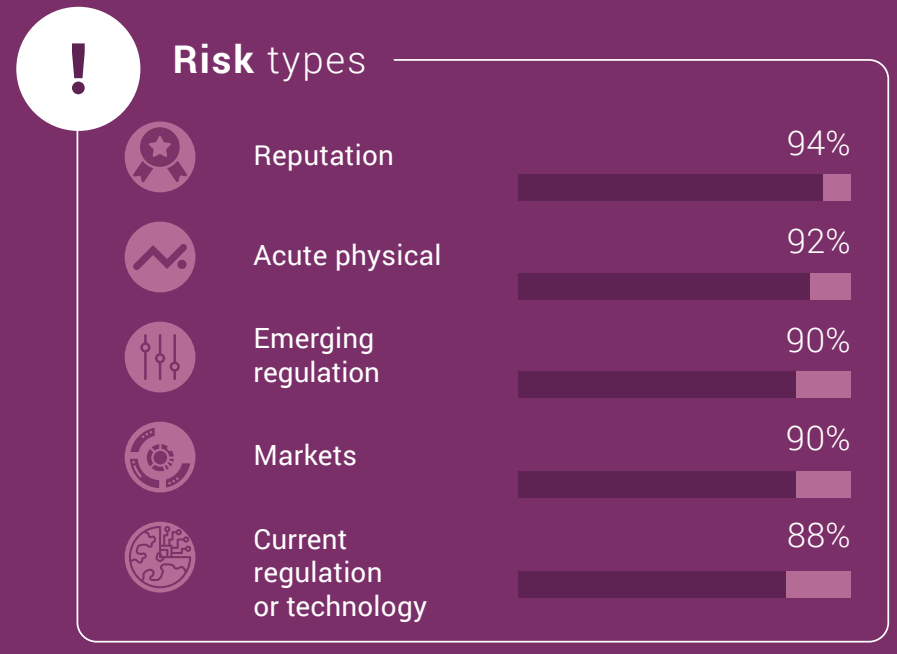

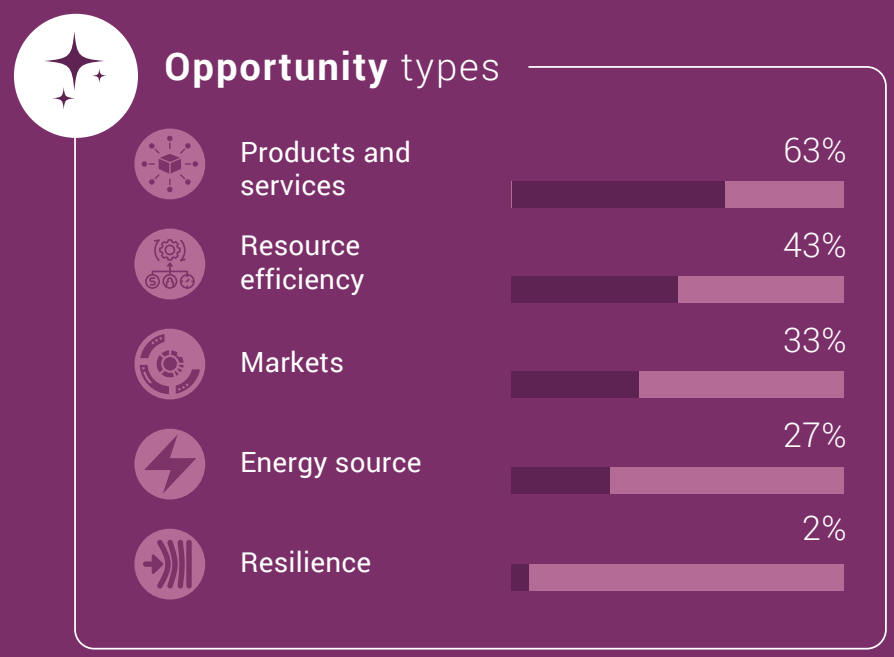

Arçelik aims to reduce total $\mathrm{CO} 2$ emissions of its domestic production plants from 2010 (base year) to 2020 by $60 \%$ by implementing new energy efficiency projects (emission reduction projects) and using the electricity generated from renewable energy sources. Thanks to energy efficiency studies and supply of electricity produced by renewable energy sources, Arçelik has reduced its $\mathrm{GHG}$ emissions by $50.27 \%$ compared to base year 2010 .

\section{Targets and Performance}

Target setting provides direction and structure to environmental strategy. Providing information on quantitative targets and qualitative goals, and progress made against these targets, can demonstrate organization's commitment to improving management of climaterelated issues at corporate level. This information is relevant to investors' understanding of how company is addressing and monitoring progress related with the risks and opportunities disclosed.
More companies are setting emissions reduction targets. Within the responding companies in Turkey, $88 \%$ have some sort of target in place for reducing emissions (84\% in 2018). Most commonly reported emissions reduction target type is intensity target (53\%). Another $27 \%$ have both intensity and absolute targets. 27 percent of companies in Turkey report that they have achieved their current intensity targets by completing their targets $100 \%$ in the reporting year and $37 \%$ reported that it is underway. 


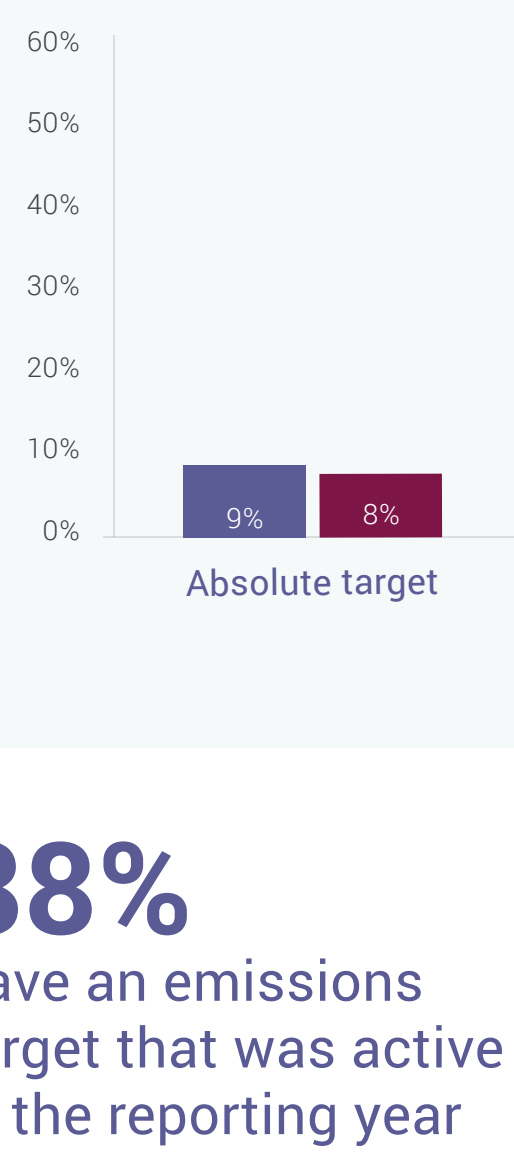

Using the most recent climate science, the science-based target setting methods determine a company's share of the remaining global carbon budget based on company attributes such as their sector and provide a pathway to companies by specifying how much and how quickly they need to reduce their GHG emissions. Targets adopted by companies to reduce GHG emissions are considered sciencebased if they are in line with the goals of Paris Agreement to limit global warming to well-below 2 degrees Celsius above pre-industrial levels and pursue efforts to limit warming to 1.5 degrees. Number of companies adopting Science Based Targets is very limited in Turkey. Only 10\% ( $7 \%$ in 2018 ) of respondents consider that their target is a science-based target, but these targets have not been approved as science-based by the Science Based Targets Initiative (SBTi). However, $41 \%$ of responding companies are anticipating setting one in the next two years.

\section{Company responses on emission} reduction initiatives allow $\mathrm{CDP}$ data users to understand the organization's commitment to reducing emissions beyond business-as-usual scenario. 88 percent of companies in Turkey report active emissions reduction initiatives in the reporting year. More than half of companies (53\%) reported that the initiatives are related to energy efficiency processes. By improving their energy efficiency, companies aim to reduce their costs.

\section{$41 \%$ \\ anticipate setting science-based emission reduction targets in the next two years}

Turkcell started its energy investment in 2016 with its subsidiary Enerjicell and established its first solar power plant in Northern Cyprus. With an installed capacity of 900 kWp, Kuzey Kıbrıs Turkcell Solar Power Plant was completed in a short period of 4.5 months with an investment of approximately 6 million TL. It is expected that 906.481 ton carbon emission will be prevented with the power plant which will produce $1,510,918 \mathrm{kWh}$ of energy to the grid over medium voltage. 


\section{$39 \%$}

\section{provide products and/or services that is classified as low- carbon products}

Questions on low-carbon products provide valuable information to investors who are seeking to increase their investment in companies providing low-carbon and climate resilient goods and services. 43 percent ( $24 \%$ in 2018 ) of companies report that their products and/or services enable third parties to avoid GHG emissions.

39 percent $(20 \%$ in 2018$)$ of companies are also working to reduce downstream emissions through the development of low carbon products and services that can help their customers to reduce emissions.
The share of renewable energy loans in total energy generation projects rose to $82 \%$. Renewable energy projects financed by Akbank yielded annual electricity generation of around 13,200 GWh and prevented 5.8 million tons of C02 emissions in 2018
Progress made against emission intensity targets (percentage of companies)

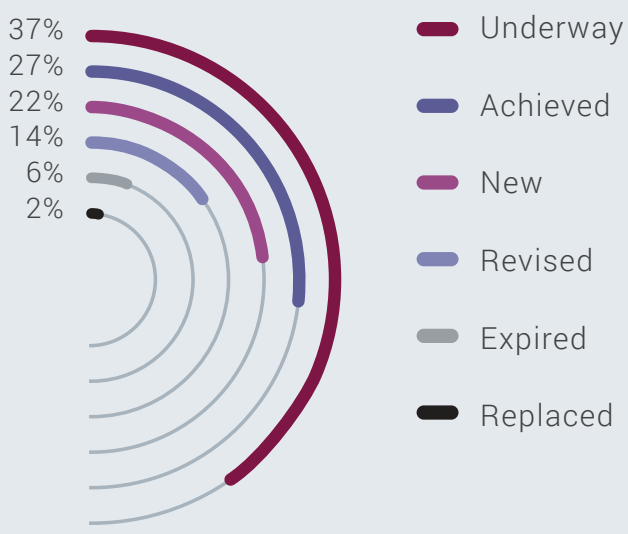

Percentage of Initiatives implemented in the reporting year / activity type

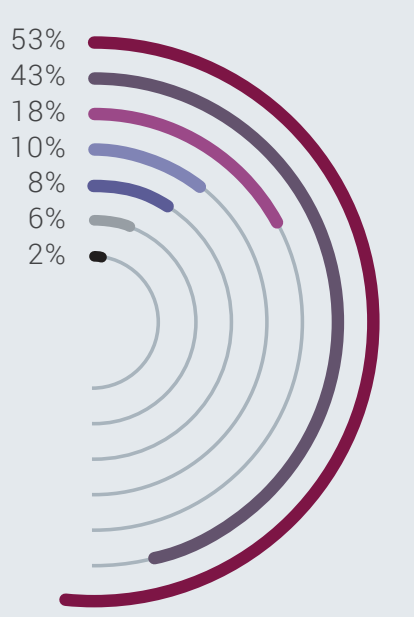

Energy efficiency: Processes

- Energy efficiency: Building services

- Process emissions reductions

$\rightarrow \quad$ Low-carbon energy installation

$\rightarrow$ Energy efficiency:a Building fabric

$\rightarrow$ Low-carbon energy purchase

- Fugitive emissions reductions
Science Based Target (status of companies)

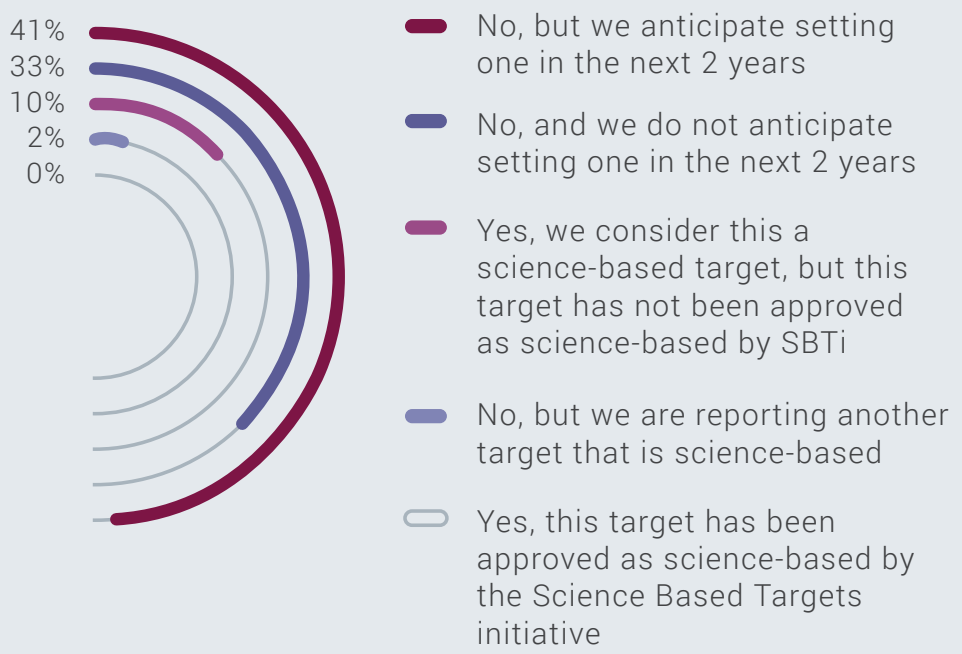

Percentage of most commonly reported methods to drive investment in emissions reduction activities

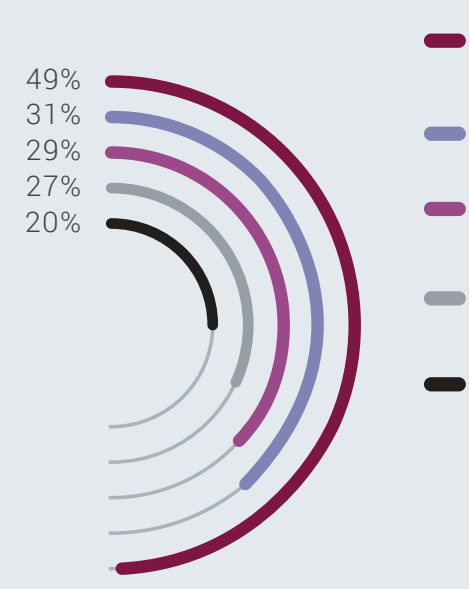

Dedicated budget for energy efficiency

Employee engagement

- Compliance with regulatory requirements/standards

Dedicated budget for low-carbon product R\&D

- Dedicated budget for other emissions reduction activities 


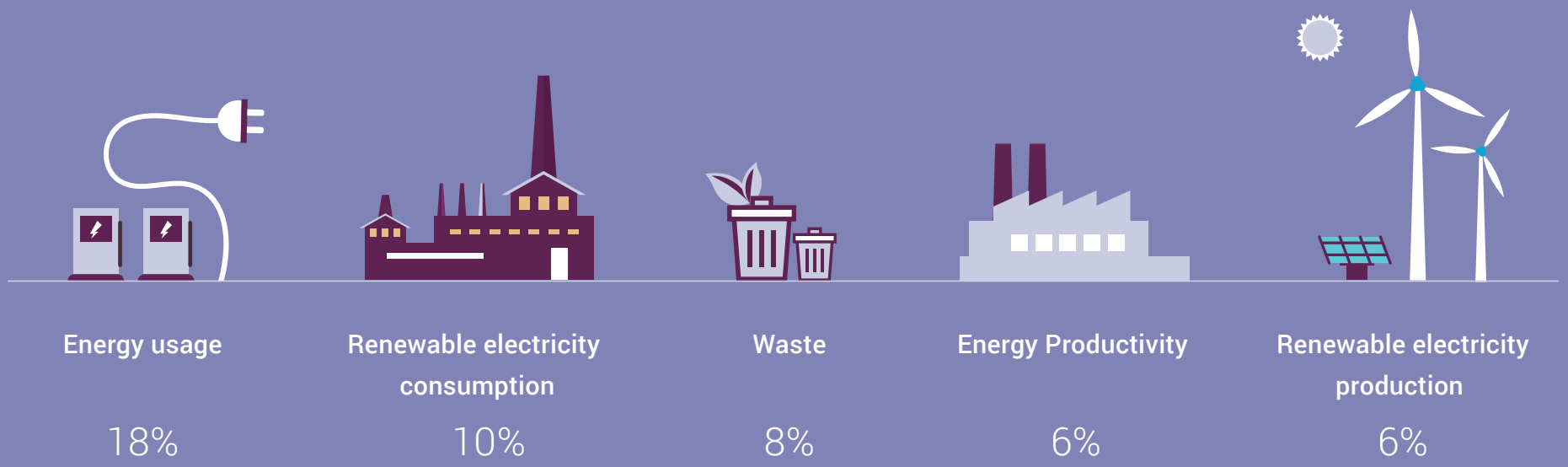

\section{$92 \%$}

reported scope $1 \& 2$ emissions

Ekoten's target is to reduce natural gas consumption per $\mathrm{kg}$ fabric by $3 \%$. These targets are set annually and are expired at the end of the year. Each year a new target is set taking into account the performance of the previous year. This year the electricity consumption per kg of fabric produced is 0.32 .
To deliver against their targets, companies are increasingly turning to clean energy, cutting emissions while simultaneously increasing their energy productivity, and reducing their energy use. Targets for replacing existing energy sources with renewable energy should form a large part of any transition strategy, but now, few companies in Turkey have set renewable energy consumption and/or production targets. 10 percent of respondents have set a renewable energy consumption target, while $6 \%$ have set a renewable energy production target.

\section{Tracking progress: Emissions trend \& verification}

Based on the disclosures of the responding companies Scope 1 \& Scope 2 emissions are concentrated heavily in two sectors: materials and industrials. In total $92 \%$ of companies from all sectors reported their Scope 1 \& Scope 2 emissions. 84 percent of responding companies also reported their Scope 3 emissions up from 82\% in 2018.

Compared to the previous years, we can see an obvious progress in Turkey in reducing emissions. 35 percent of companies did report an absolute increase in Scope 1 and Scope 2 emissions in 2019 from 2018 and $76 \%$ (45\% in 2018 compare to 2017 ) report an absolute decrease in emissions over the past year.
Gross global emissions (Scope 1 and 2 combined) for the reporting year compare to those of the previous reporting year

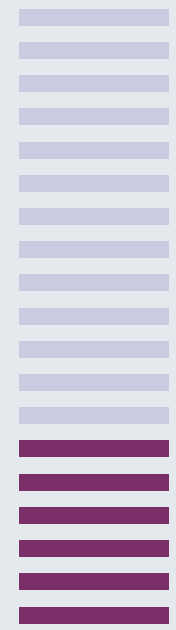

Increased $36 \%$

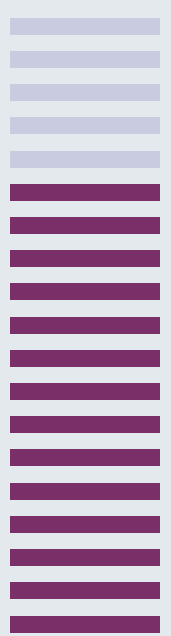

Decreased $76 \%$ 


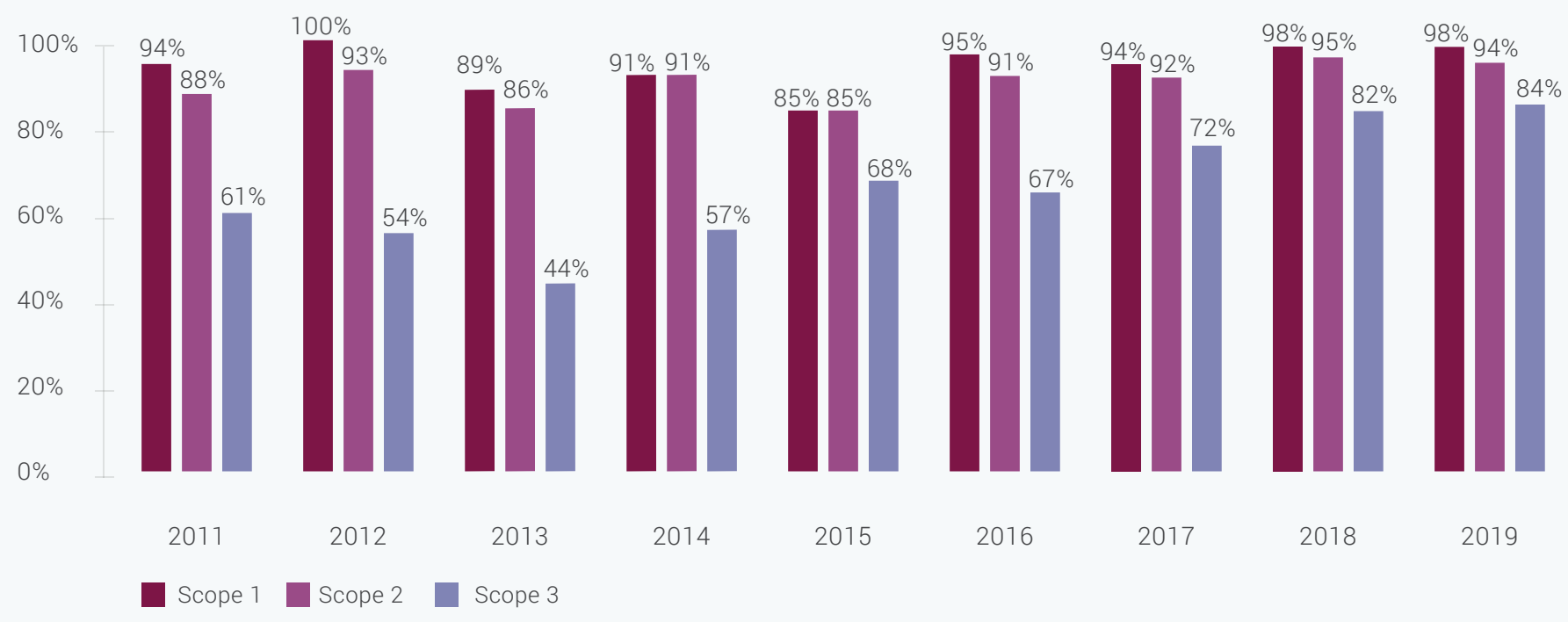

\section{$82 \%$}

Scope 1 \& 2 emissions have been externally assured or assurance is underway

\section{$96 \%$}

provide energy consumption totals
Third-party verification and assurance ensure the quality of data and processes disclosed. A growing number of companies in Turkey recognize the importance of verifying the accuracy of their emissions data. 82 percent of responding companies in Turkey indicated that their Scope 1 and Scope 2 emissions have been externally assured or assurance is underway, an improvement over $75 \%$ in 2018. Since Scope 3 emissions are often more difficult to quantify when compared to Scope 1 and Scope 2 emissions, the level of the third-party verification is comparatively lower in this area: 47 percent ( $41 \%$ in 2018$)$.

Energy-related activities represent the most significant $\mathrm{GHG}$ emission sources. Accurate emissions accounting depends on a comprehensive account of energy. Almost all companies (96\%) in Turkey provides energy consumption totals (excluding feedstock) in MWh including energy consumption totals from renewable sources (41\%). Further $92 \%$ provides fuel consumption by fuel type consumed by the company.

Renewable energy sourcing helps companies reduce expenditures on electricity. In the reporting year, responding companies in Turkey consumed 49 TWh electricity in their operations of which 4.5 TWh came from renewable energy sources.

Operational spend on energy is a strong indicator for a company to investigate opportunities to reduce cost while ensuring emission reductions through the adoption of low carbon energy options. In Turkey, $43 \%$ of companies have reported that $0-5 \%$ of their total operational spend was on energy (electricity, fuel, etc.).

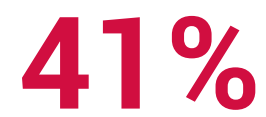

energy consumption totals from renewable sources in MWh 


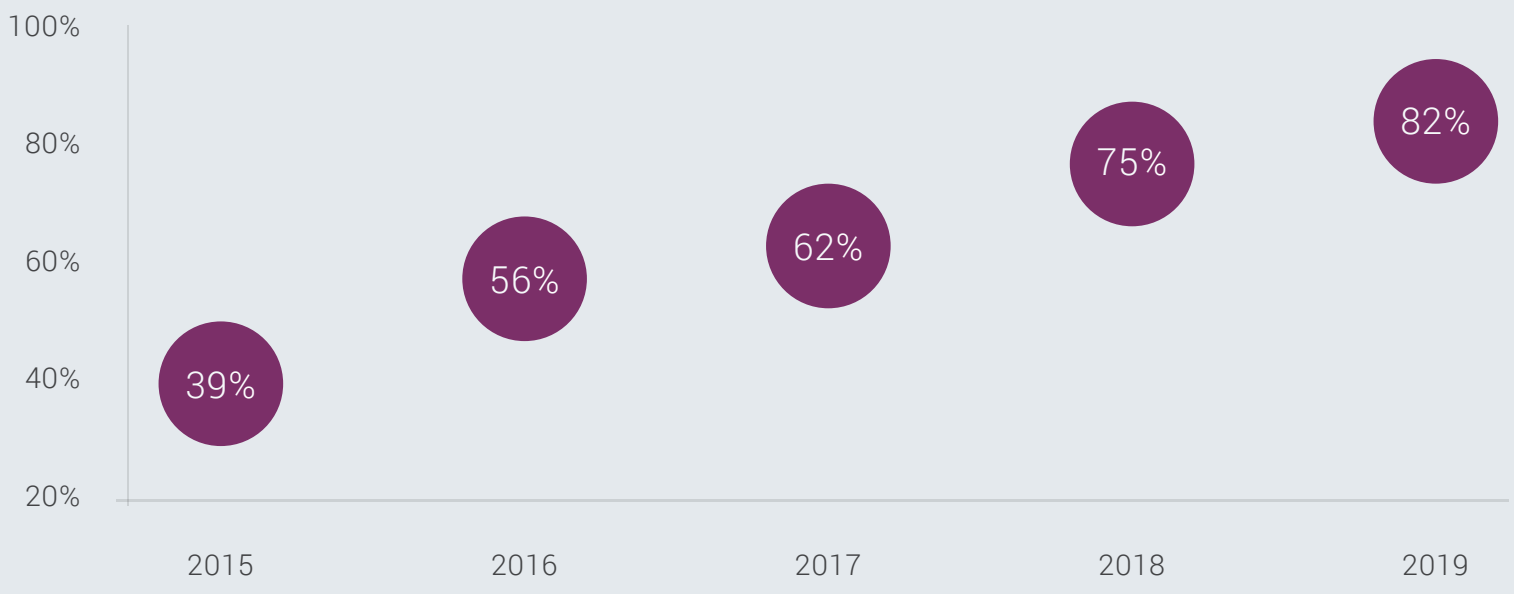

\section{$22 \%$}

engage with more than 50 percent of suppliers to drive emission reductions

\section{Vngagement}

In order to truly reduce global emissions, companies must engage with their value chain on climate-related issues. Companies in Turkey are engaging with key stakeholders such as policymakers, suppliers, and customers. 53 percent ( $41 \%$ in 2018 ) of companies engage with their value chain on climaterelated issues but only $22 \%$ engage with more than $\% 50$ of suppliers by number. Moreover, $96 \%$ (86\% in 2018) of respondents reported engagement in activities that could either directly or indirectly influence public policy on climate-related issues.

The percentage of companies sitting on the board of any trade associations or provide funding beyond membership is $57 \%$. 84 percent of companies published information about organization's response to climate change and GHG emissions performance for this reporting year in places other than CDP response. Further 59\% (52\% in 2018) published voluntary sustainability report. Since TCFD recommendations call for disclosure of climate-related information in financial reports, companies should be aware that their financial reporting is expected to include environmental information at the same level of CDP responses.
$57 \%$

sitting on the board of any trade associations or provide funding beyond membership
$59 \%$

published voluntary sustainability report 


\section{COMPANY RESPONSE SUMMARY WATER SECURITY / TURKEY 2019}

\section{GOVERNANCE \& BUSINESS STRATEGY}

This module captures the governance structure and mechanisms of the organization with regards to water security. It provides data users with an understanding of the organization's approach to water-related issues at the board-level and below board-level. The purpose of this module is to collect information on how a company is adapting its long-term business model to secure a sustainable future, in terms of both its own resilience and securing water for all. This module also collects information on organization's waterrelated quantitative targets and qualitative goals to demonstrate the commitment to progressing water stewardship and improving water management.

(

$90 \%$ of the respondents have a company-wide water policy

-65\% of the respondents identified any water-related outcomes from the organization's climate-related scenario analysis

v $19 \%$ of the respondents use an internal price on water

V $\mathbf{5 8} \%$ of the respondents identified reduced environmental impacts as primary motivation behind the water-related targets

\section{VERIFICATION}

CDP data users often ask about the credibility/quality of data disclosed. The information requested in this question could help strengthen confidence in organization's response to the water security questionnaire. CDP supports the development and use of verification methodologies as it promotes good practice in environmental disclosure.

V $\mathbf{4 5 \%}$ of the respondents verified water consumption

$\checkmark \mathbf{4 2} \%$ of the respondents verified water discharge

$\checkmark \mathbf{1 9} \%$ of the respondents verified water recycle/reuse

V5\% of the respondents verified water withdrawals

\section{OPPORTUNITIES}

The structure of the water security questionnaire allows a company to tell investors, customers and other data users about its water stewardship journey. That's why CDP also invites companies to share any water-related operational or market opportunities being realized that could substantively benefit their business. With this module data users now understand the current state of a company's use of water and how water-related opportunities are identified.

$\nabla 87 \%$

$\mathbf{8 7 \%}$ of the respondents identified water-related opportunities with the potential to have a substantive financial or strategic impact on the business

Primary water-related opportunities:

- $48 \%$ Cost savings

- $32 \%$ Improved water efficiency in operations

\ $23 \%$ Increased brand value

- $16 \%$ Sales of new products/services

- $16 \%$ Increased sales of existing products/services

- $13 \%$ Stronger competitive advantage

\section{LINKAGES \& TRADE-OFFS}

This module asks about linkages and trade-offs that may have been identified and/or considered when taking actions to manage risks or pursue opportunities related to water and other environmental issues. Understanding the linkages and trade-offs between water and other environmental issues will help companies seize opportunities for more holistic management.

26\% decreased energy use is the most common reported type of linkage

च $29 \%$ increased energy use is the most common reported type of trade-off 


\section{CURRENT STATE \& ACCOUNTING}

The information in this module allows CDP data users to build a picture of the dependence of company's direct operations and wider value chain on sufficient amounts of water of a particular quality, currently and for future growth, and where in the value chain most dependence on water lies. To understand an organization's resilience, it is important to understand the potential to reduce reliance on freshwater sources. The questions allow company to demonstrate how well it understands its corporate hydrology by providing information on the monitoring of relevant water aspects, and volumetric data on withdrawals including withdrawals in water stressed areas, discharges, consumption, and recycling.

- $\mathbf{9 0} \%$ regularly measured and monitored $100 \%$ of the water aspects across all operations

v $39 \%$ more than $50 \%$ of total withdrawals sourced from water-stressed areas

V $\mathbf{7 1 \%}$ of total water withdrawal sourced by third party sources

V $6 \mathbf{6 \%}$ of the respondents provide water recycle or reuse percentages

V $\mathbf{1 9 \%}$ of the respondents request from more than $50 \%$ of suppliers to report on their water use, risks and/ or management information

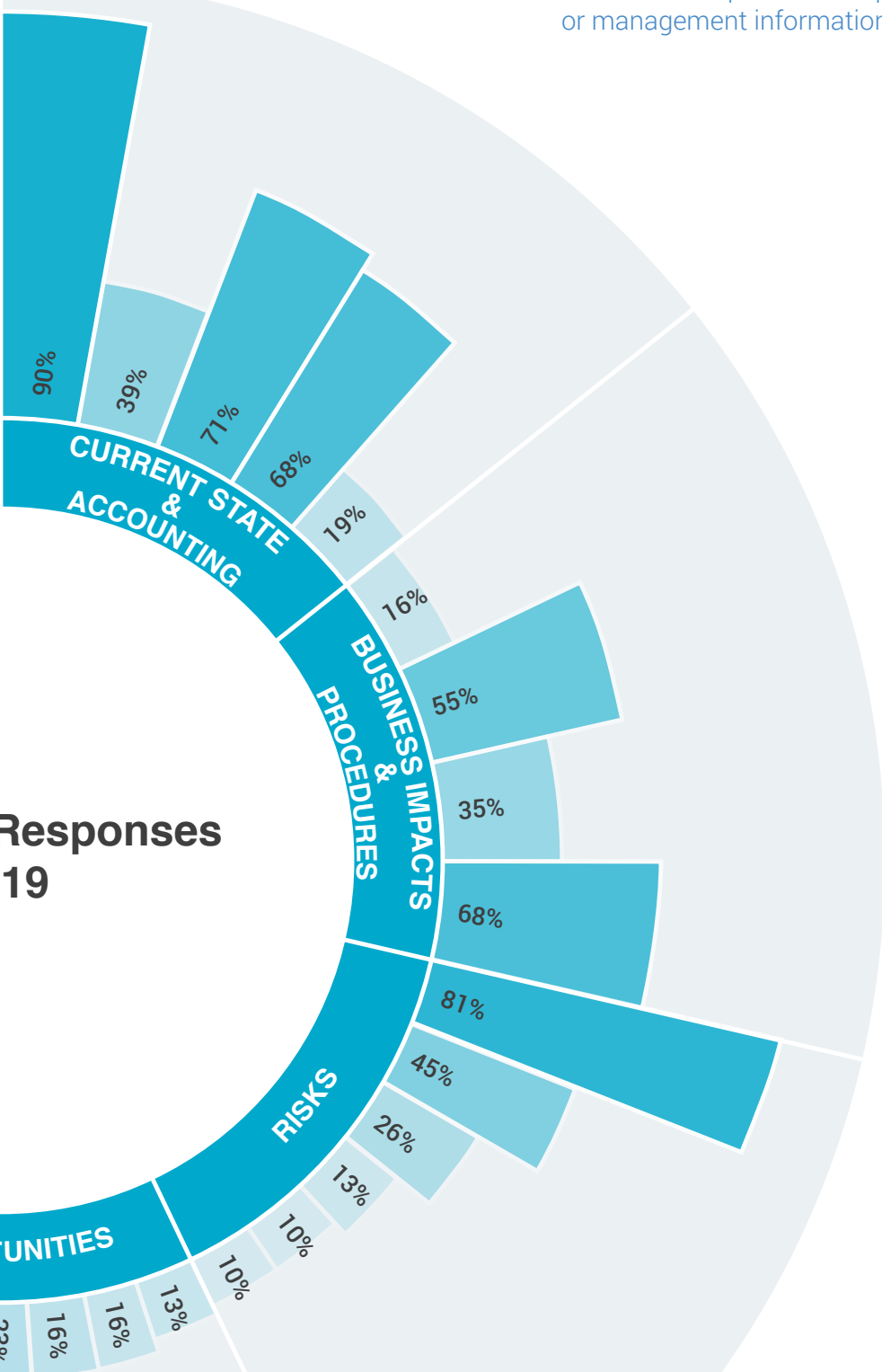

\section{BUSINESS IMPACTS \& PROCEDURES}

This module asks about water-related impacts on organization and response to them. These are impacts that have occurred in the past reporting year, including those resulting from regulatory violations. Procedures module requests information about the procedures that organizations have in place to manage issues salient to their sector and to understand inherent risk exposure. These management procedures are considered important for water security - independent of a company's own perception or assessment of any associated net risk for their company. This is why CDP asks companies to answer these questions before disclosing whether they consider themselves exposed to substantive water-related risk and what those risks are.

V $16 \%$ flooding is the most reported impact driver of the waterrelated detrimental impacts experienced by the company

V $\mathbf{5 5 \%}$ of the respondents assessed water risks as part of the other company-wide risk assessment systems

V $35 \%$ of company procedures for identifying and assessing waterrelated risks covered both direct operations and supply chain

च $68 \%$ assessed water-related risks for more than 10 years

\section{RISKS}

An understanding of the number, location and nature of inherent water risks is valuable for disclosing companies, as well as CDP data users. This module allows companies to show that they have a clear awareness of the extent to which they are exposed to inherent water risks in their direct operations and other parts of their value chain. CDP asks companies to report substantive water-related risks, the potential impacts of those risks and share details of their associated response strategies.

\section{$\mathbf{8 1} \%$ of the respondents identified inherent water-related risks with the potential to have a substantive financial or strategic impact on the business}

\section{Potential impacts of identified risks in the direct operations are:}

\ $45 \%$ Increased operating costs

V $26 \%$ Reduction or disruption in production capacity

- $13 \%$ Brand damage

v $10 \%$ Closure of operations

- $10 \%$ Increased production costs 


\section{COMPANY RESPONSE OVERVIEW}

WATER SECURITY / TURKEY 2019

\section{2 \\ disclosing companies in total}

Although the regulations at the national level are not yet pressurizing or encouraging companies in Turkey to address water risks, the new climate regime requires companies to be sufficiently transparent on environmental and water-related risks and opportunities relevant for their businesses.

CDP's water security questionnaire motivates companies to disclose and reduce their environmental impacts by using the power of investors and customers. The data CDP collects help influential decision makers to reduce risk, capitalize on opportunities, and drive action towards a more sustainable world. CDP also works with a range of organizations; such as the CEO Water Mandate, the World Resources Institute (WRI), WWF, World Business Council for Sustainable Development (WBCSD), the Global Reporting Initiative (GRI), the Alliance for Water Stewardship, Ceres, Sustainability Accounting Standards Board (SASB) and similar organizations in order to support the development of standards that are both valuable for companies and provide investors, policy makers and other data-users with meaningful information. Standardization is needed to facilitate transparency and reporting as well as to support consistency and comparability for data users.

Through water questionnaire, CDP asks companies to systematically report data relating to their water use, waterrelated risks and opportunities and their governance of water. Investors use CDP water data to engage with portfolio companies, inform investment decisions, and catalyze change. In addition, more than 125 purchasing organizations use CDP water data to drive greater insight, accountability, and action throughout their global supply chains. Globally, $\mathbf{8 4 4 3}$ companies disclosed to CDP water program in 2019.
On behalf of investor signatories, in the fifth year of the CDP Water program in Turkey, we asked 50 companies to provide data about their efforts to manage and govern freshwater resources. We selected these companies based on economic and environmental indicators (largest listed companies in high water impact industries). In total, 32 companies responded to CDP's water program in Turkey up from 27 companies ( $19 \%$ increase) in 2018 . Out of 32 respondents, 14 were self-selected (SSCs) and 17 were included in the Turkey sample that received an official invitation. Therefore, the response rate of the official sample is $34 \%$ (28\% in 2018).

This chapter presents summary findings from our analyses of 31 (one of the companies is Self-Selected Company) responding company disclosures in response to the CDP Water Information Request. 


\section{$71 \%$}

\section{water quality \& quantity is important for the success of the business}

Water is not added as a raw

material into Arçelik's products but

dishwashers and washing machines

use water in consumer product usage

phase. Because of these products

work with freshwater, Arçelik engage

and raise customers' awareness by

advertisements, documentaries, and

publications related to water efficiency

and by producing best water efficient

products. To decrease customers'

water consumption and risks, R\&D

projects are being developed. As an

example, Arçelik has developed a new

dishwasher, which has lower water

consumption with seven liter per usage

while having optimum performance

and efficiency.

\section{Measuring and Monitoring}

Robust water accounting data is necessary to inform business planning and forecasting as well as risk identification and response. Measuring and monitoring water usage, discharge and consumption are vital first steps in enabling companies to understand the risks they face, and the opportunities available to improve water security and stewardship throughout their operations and supply chains.

Companies should regularly measure all water aspects: withdrawals, discharges, quality, consumption, and employee access to WASH (Water, Sanitation, and Hygiene).

This module allows CDP data users to build a picture of the dependence of company's direct operations and wider value chain on sufficient amounts of water of a particular quality, currently and for future growth, and where in the value chain most dependence on water lies.

CDP asks companies to rate the importance (current and future) of water quality and water quantity to the success of their business. The companies
Water is vital for Akenerji's operations.

Especially at Hydroelectric Power

Plants (HEPP), electricity can be

generated by means of water.

The potential energy of water is

transformed to mechanical energy

to generate electricity. Therefore,

availability of water (water quantity)

is vital for Akenerji's operations.

Besides, Akenerji have a natural gas

combined cycle power plant (NGCCPP)

and significant volume of water is

necessary for cooling purposes.

disclosing from Turkey claim that having sufficient good quality freshwater for their own use is either important $(71 \%)$ or vital (58\%) for their business.

A significant portion of responding companies (94\%) reporting via CDP now measure and monitor more than $50 \%$ of all water aspects across all operations (sites/facilities/operations). Rather 90\% are regularly measure and monitor all (100\%) water aspects. However, only $45 \%$ of responding companies in Turkey require their key suppliers to report water use, risk, and management.

Percentage of companies that regularly measure and monitor more than $\mathbf{5 0} \%$ of all water aspects across all operations

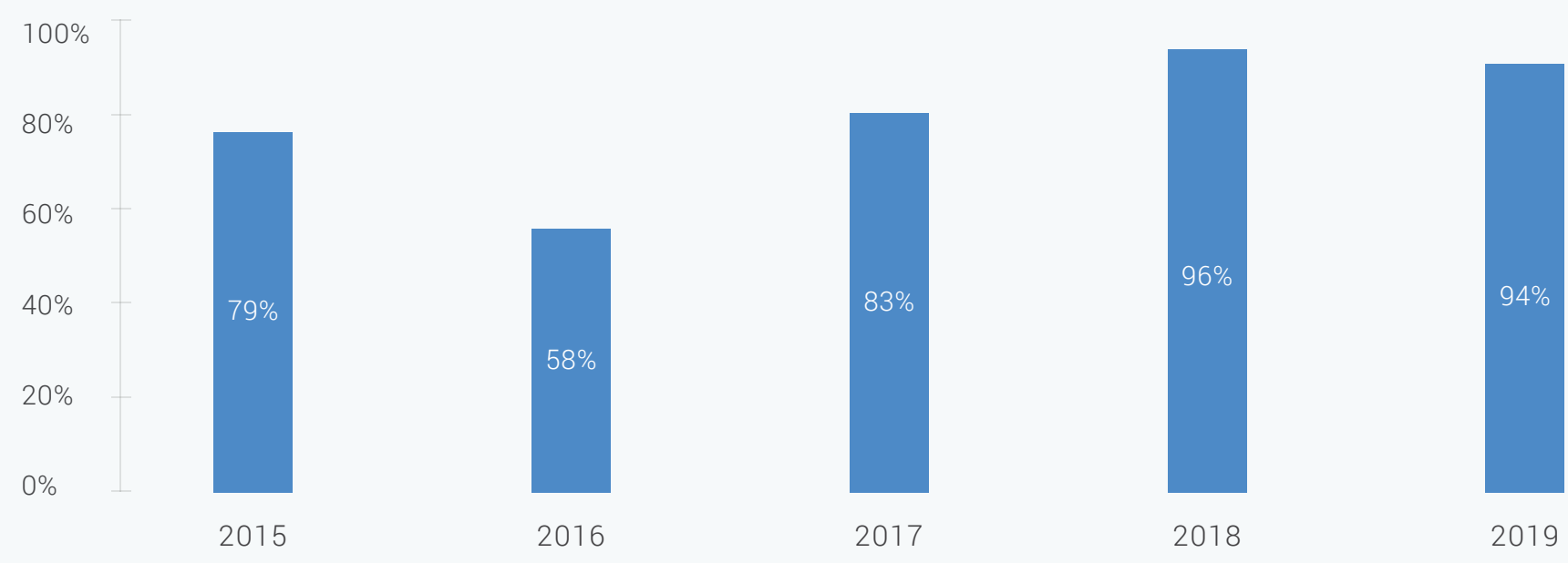




\section{$71 \%$}

water withdrawal is sourced from third party sources

In Ford Otomotiv, third party sources withdrawal during the reporting period has decreased by $17.33 \%$ compared to previous year. The reason for this decrease is water consumption related projects at its Sancaktepe facility.

\section{$68 \%$}

provide water recycle or reuse percentages

In Tekfen, the total amount of water recycled/reused has increased by 18.77\% (1,576 megaliters) from 2017 to 2018 , reaching $24 \%$ of total water consumed. During energy production from waste heat recovery, Tekfen first demineralize the water. Some of the demineralized water is condensed and re-used. These recycled and reused water quantities are very high in company's Samsun and Mersin plants. Water is reused for coal dust suppression in Ceyhan Plant and Tekfen Construction reuse the hydro test water for concrete washing.
As per accounting of water use, $94 \%$ (92\% in 2018) of responding companies gave account of their water withdrawals by source via CDP. A further $94 \%$ also provided total water discharge data by destination. While $48 \%$ (27\% in 2018) of responding companies have measured that, their water consumption is lower than the previous year, $26 \%$ ( $27 \%$ in 2018 ) of the companies report an increase. In terms of water withdrawals, $52 \%$ (38\% in 2018) of responding companies report a decrease, while $26 \%$ (35\% in 2018) measured an increase compared to previous year. The most common explanation that companies provide for increased withdrawals is an increase in production. 55 percent $(46 \%$ in 2018) of companies reported that total water discharge by destination is lower compare to the previous year.

Most of the water withdrawal is sourced from third party sources $(71 \%)$ and most of the water is discharged to third party destinations $(81 \%)$ which shows water crosses the company boundary, at either the corporate level or facility level.

39 percent of responding companies reported that more than $50 \%$ of total withdrawals sourced from water stressed areas. 10 percent of companies reported that total water withdrawals sourced from water stressed areas are higher compare to the previous reporting year.

68 percent (58\% in 2018) of responding companies provide water recycle or reuse percentages and $19 \%$ of companies reported that more than $50 \%$ of total water use is recycled and reused. 13 percent ( $4 \%$ in 2018) reported that the total volume of recycled and reused water use is lower and $26 \%$ ( $15 \%$ in 2018 ) reported that it is higher compare to the previous year.

\section{$48 \%$}

water consumption is lower than the previous year

\section{$39 \%$}

more than $50 \%$ of total withdrawals sourced from water stressed areas

\section{2,646 megaliters volume of total water withdrawal by source}

${ }^{2}$ A Representative Concentration Pathway (RCP) is a greenhouse gas concentration (not emissions) trajectory adopted by the IPCC. Four pathways were used for climate modeling and research for the IPCC fifth Assessment Report (AR5) in 2014. The pathways describe different climate futures, all of which are considered possible depending on the volume of greenhouse gases $(\mathrm{GHG})$ emitted in the years to come.

Water data comparison with previous reporting year

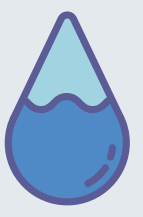

$55 \%$

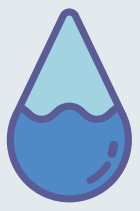

$52 \%$

Total water withdrawal by source is lower compare to the previous year

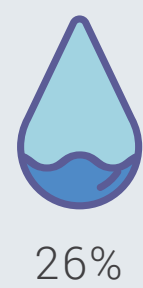

Total volume of recycled and reused water use is higher compare to the previous year
Total water discharge by the previous year 


\section{The most frequently cited water withdrawal sources and water discharge destinations}
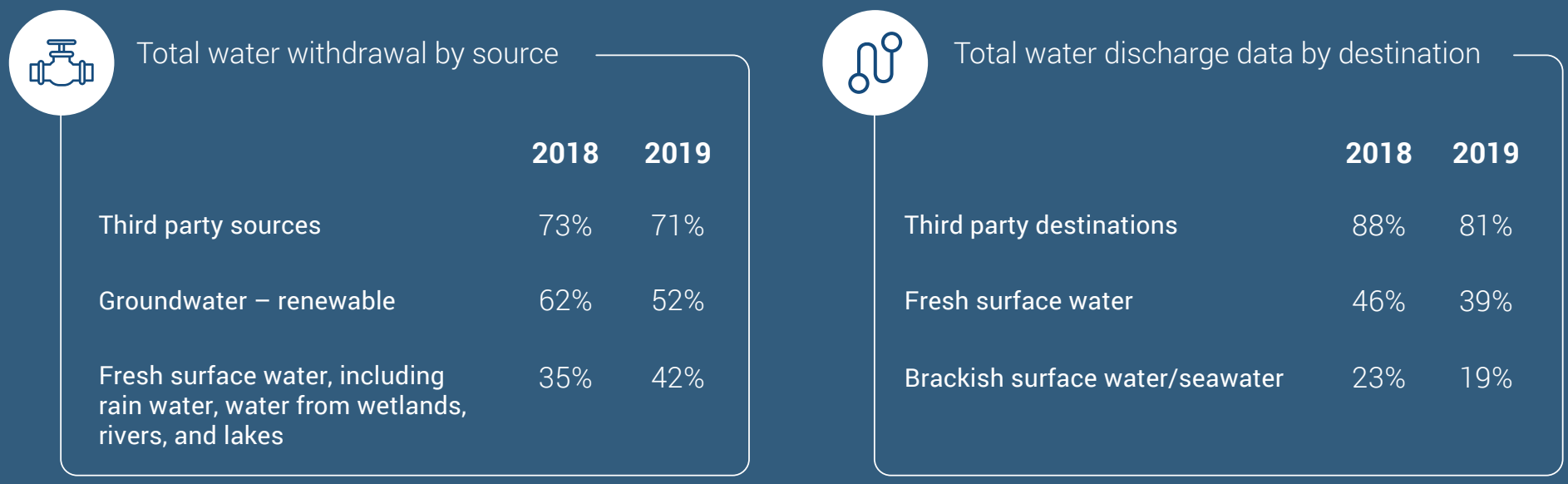

\section{$87 \%$}

\section{engage with the value} chain on water-related issues
The module also asks about engagement activity around water in the value chain and a rationale for it. In regions where water sources are highly restricted, organization's water consumption patterns can influence relations with other stakeholders and access to water can be dependent on those relationships. 87 percent $(69 \%$ in 2018 ) of responding companies engage with the value chain on water-related issues. 45 percent $(38 \%$ in 2018) of respondents also ask their suppliers to report on their water use, risks and/or management information and a further $19 \%$ require more than $50 \%$ all of those aspects to be reported by their suppliers.

Water withdrawals are the most externally verified water accounting data (55\%). 39 percent of respondents verified other water information besides the company's CDP disclosure on the following items.
Migros attaches a great importance to supplier selection and monitors suppliers' practices within the framework of its responsible sourcing approach and assists them to improve their performance, including water use, risks, and management. In 2018, $85 \%$ of its suppliers, which make up company's $80 \%$ of total revenue, was selected as a target sample according to $80 / 20$ rule known as the Pareto Analysis. That significant amount of suppliers have a massive impact on the company.

\section{Percentages of externally verified water accounting data}

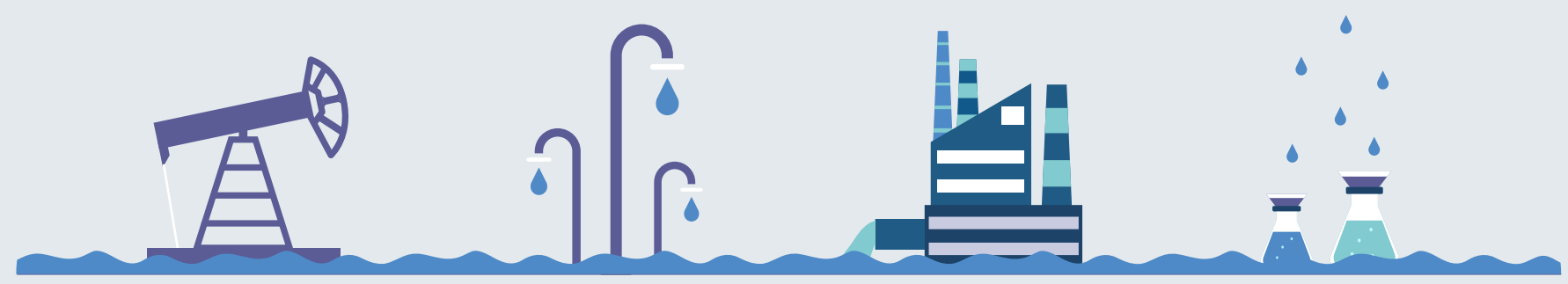

Water withdrawals

Water consumption

Water discharge

Water recycled/reused

$55 \%$

$45 \%$

$42 \%$

19\% 


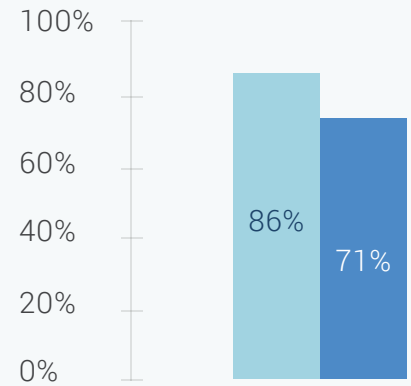

2015

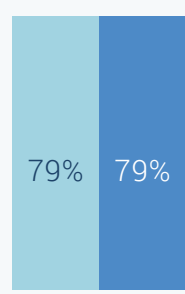

2016

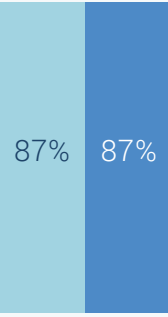

2017

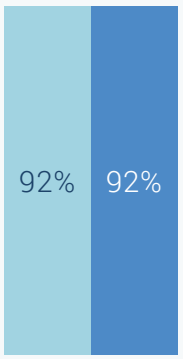

2018

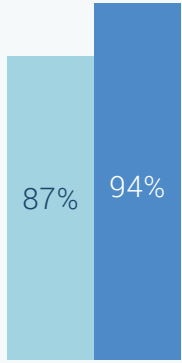

2019

Total water withdrawal data by source

Total water discharge data by destination

Percentage of respondents require suppliers to report on their water use, risks and/or management information

\begin{abstract}
$0 \%$
\end{abstract}
$50 \%$

$40 \%$

$30 \%$

$20 \%$

$10 \%$

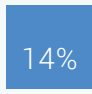

2015

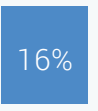

2016

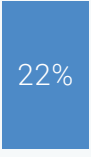

2017

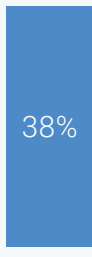

2018

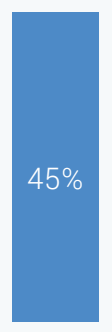

2019

\section{$32 \%$}

\section{experienced}

detrimental waterrelated impacts

Kordsa's Izmit facility has

experienced flooding due to

mismanagement of the nearby

Yuvacık Dam. Following a heavy

rain, the dam storage was over

capacitated and in order to release

the access water and maintain

services, the dam gates were opened,

resulting in additional water for the

basin where company's facility is

located. Part of their production

process was affected, and it caused

reduced output.

\section{\ Business Impact \& Procedures}

There are financial risks that companies face from water issues. 32 percent of companies in Turkey suffering from some sort of waterrelated issue (experienced detrimental impacts) over the reporting periodmostly related to flooding or droughts.

A comprehensive risk assessment is essential for companies to develop a clear understanding of physical, regulatory, and reputational exposures as well as opportunities available. 94 percent of responding companies state that water risks are assessed. However, water-exposed companies should conduct risk assessments that

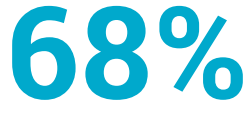

assessed water-related risks for more than 10 years

ENKA undertakes a comprehensive

company-wide water-related risk

assessment as well as developing

separate risk assessments for each

of its projects involving its suppliers.

Before the construction of projects,

Environmental and Social Impact

Assessment Reports are prepared

by external consultants to identify potential impacts the project may have on the environment as well as defining water-related risks the project may pose. 


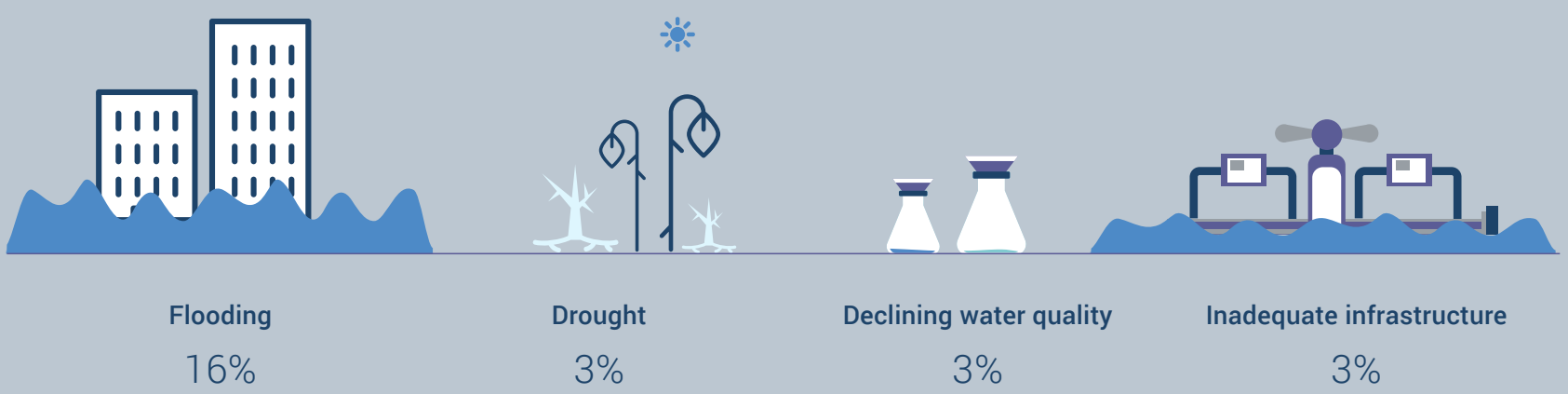

Percentage of companies assessed their water-related risks including direct operations and supply chains

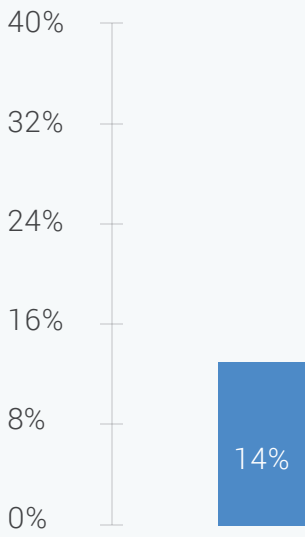

2015

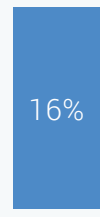

2016

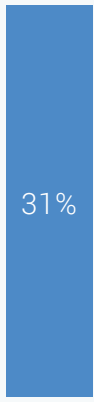

2018

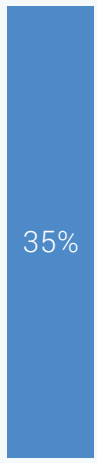

2019
In Zorlu Enerji, while assessing waterrelated risks, they prioritize water availability and quality at each power plant under our operational control. As water is vital for their operations mainly in thermal power plants, waterrelated risks in terms of implications in cases of not having water at sufficient amounts are assessed covering the whole lifetime of each plant. While conducting water risks assessment they use WRI Aqueduct tool and internal company knowledge. are company-wide and comprehensive, including their direct operations and their supply chains. $35 \%$ of disclosing companies meet this higher standard. 68 percent of companies assessed water related risks for more than 10 years - up from $35 \%$ in 2018.

Water is a local issue and each river basin faces distinct challenges as a function of the different water users operating there. Assessment at the basin level poses challenges for companies, given that it requires an understanding of the activities and needs of local communities and other local water users. 65 percent of companies in Turkey conduct risk assessment, which took place at the river basin level - up from $58 \%$ in 2018 - and $90 \%$ (85\% in 2018) of responding companies factor local communities into their water risk assessments. 


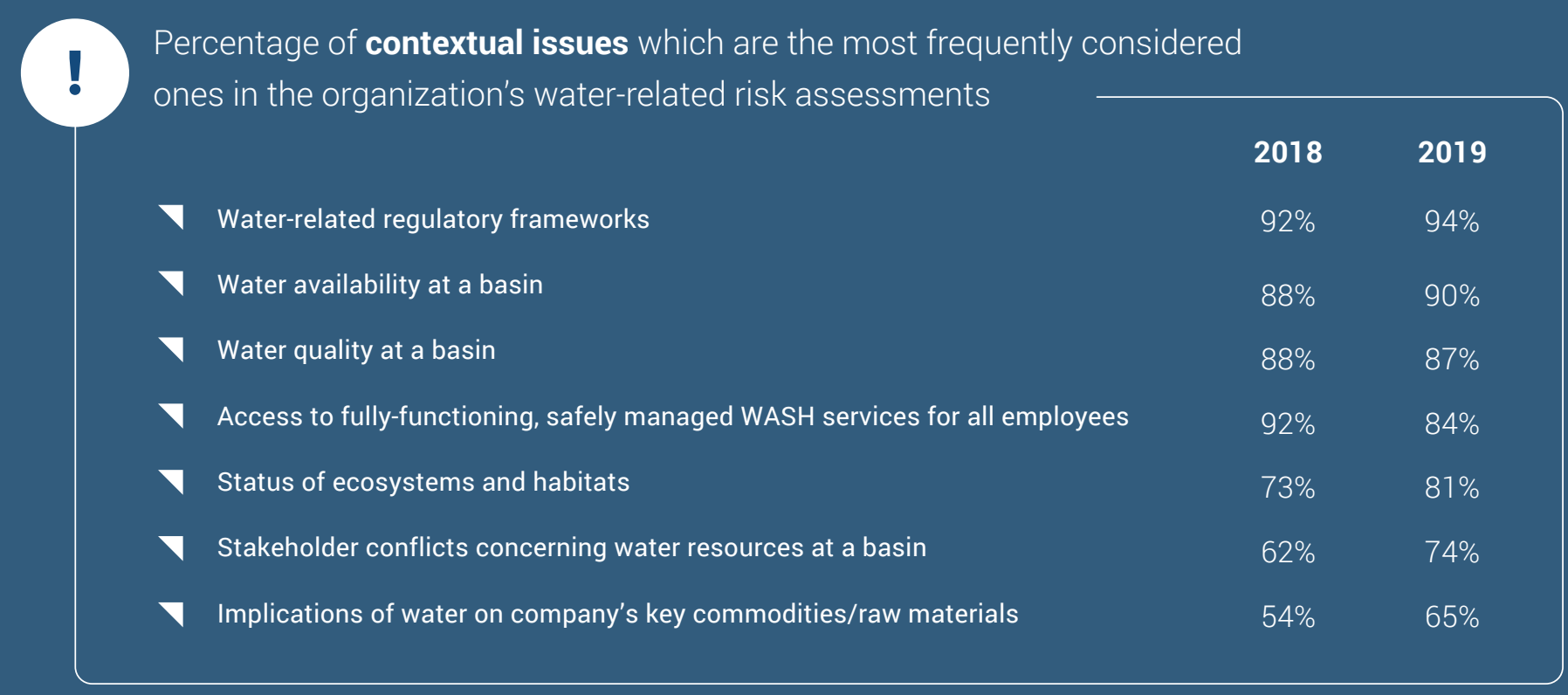

Stakeholders which are always considered in the organization's water-related risk assessments

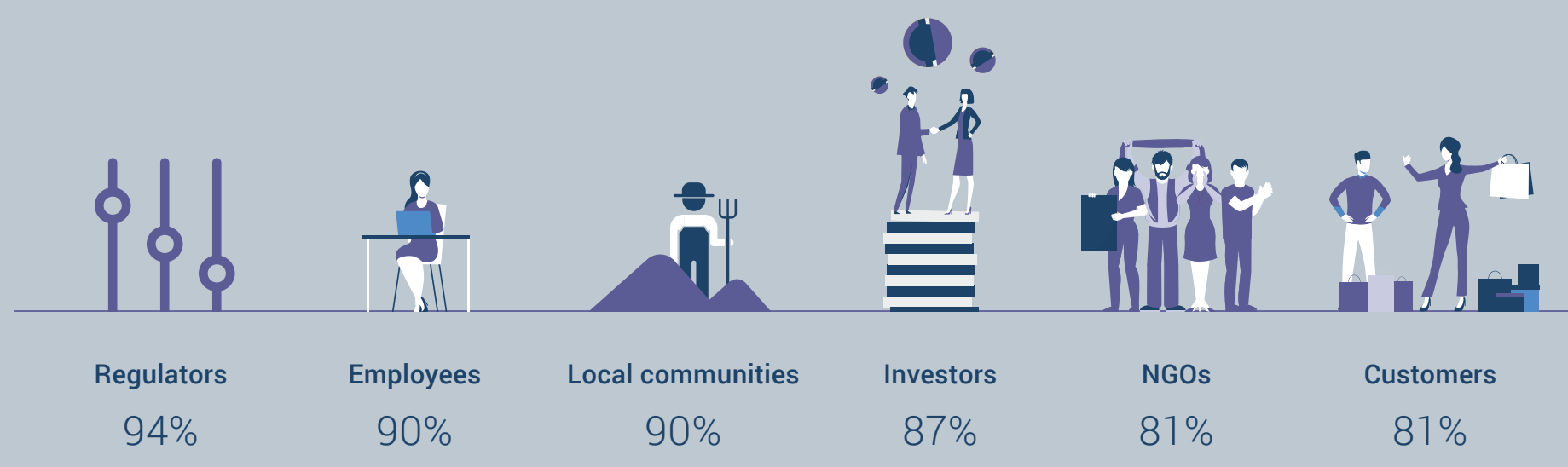

Şekerbank assesses the water risks

from three different aspects: 1- Risks to physical operations 2-Risks transferred to them through their costumer portfolio 3- Risks of their suppliers.

They try to follow and manage these risks through risk management tools developed in-house.

\section{\ Risks Assessment \& Opportunities}

A company considering its water use alongside the physical, regulatory, social, environmental and temporal context within which it and its suppliers operate, has a far greater chance of understanding and enhancing its resilience. Companies are asked to report substantive water-related risks and to share any water-related opportunities being realized that could substantively benefit their business.

Companies should undertake water risk assessment that account for the regional context in both direct operations and supply chains. 48 percent ( $46 \%$ in 2018 ) of responding companies identified inherent water-related risks with the potential to have a substantive financial or strategic impact on the business both in direct operations and in the rest of our value chain. By improving their understanding of

\section{$48 \%$}

identified water-related risks both in direct operations and the rest of the value chain

Water is essential for Brisa's production process. In order to prevent waterrelated disruption in their production, a) they continuously monitor the availability and the quality of water withdrawal in all production facilities; b) they try to prevent supply chain related disruption via generating a supplier pool from which we are able to choose multiple suppliers providing the same raw material. 
The most frequently reported primary risks and opportunities

\begin{tabular}{lrr}
\hline Primary risk drivers in the direct operations \\
Flooding & $\mathbf{2 0 1 8}$ & $\mathbf{2 0 1 9}$ \\
Increased water scarcity & $27 \%$ & $29 \%$ \\
Increased water stress & $27 \%$ & $26 \%$ \\
Drought & $23 \%$ & $26 \%$ \\
Declining water quality & $23 \%$ & $23 \%$ \\
Higher water prices & $19 \%$ & $19 \%$ \\
\hline
\end{tabular}

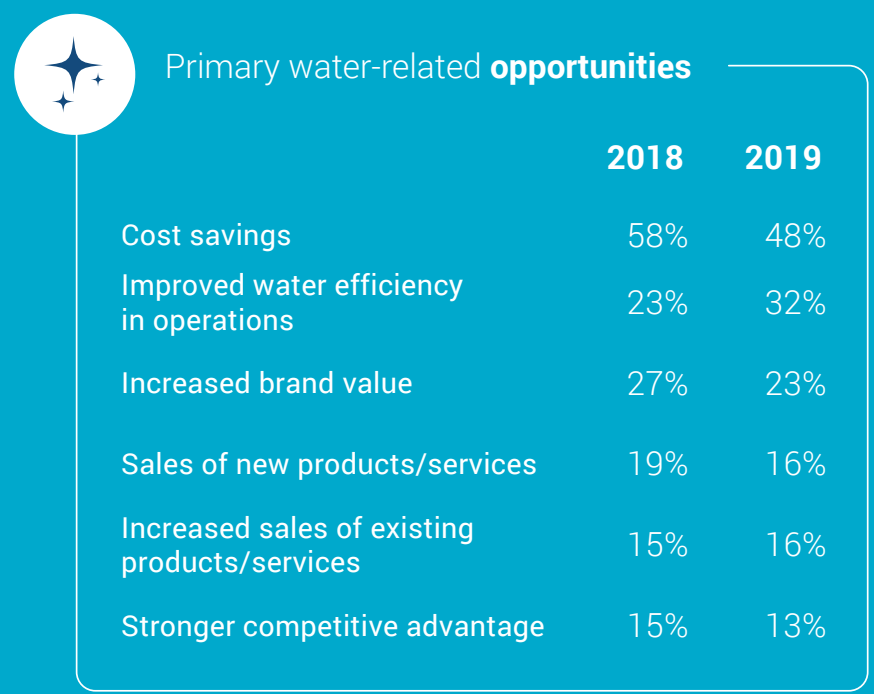

\section{$77 \%$}

\section{identified physical} risks in the direct operations

\section{$48 \%$}

\section{anticipate risks to} materialize within 1 - 6 years in direct operations the way in which water is managed around them, companies are better prepared to respond proactively to challenges.

58 percent of responding companies reported that more than $50 \%$ of companywide facilities are exposed to water risks. That percentage at the facilities on river basin is $48 \%$.

Physical risks are the most reported types of risks in the direct operations $(77 \%)$ and in the value chain (42\%). Increased operating costs are the most reported potential impact $(45 \%)$ of identified risks in the direct operations; in the value chain, the most reported risk drivers are drought (13\%) and flooding (13\%).

48 percent of companies anticipate that the substantive financial or strategic impacts of identified risks in direct operations will be realized within one to six years. A further $52 \%$ anticipate that it is going to realize over a period more than six years.
According to Coca Cola i̇çecek, because of climate change, change in extreme weather conditions such as heavy rainfall in a short amount of time is starting to be observed. Additionally, due to extreme urbanization, water penetration beneath the soil becomes hard and less, consequently water surface run off increases. Coming together with inadequate drainage / sewage systems, the risk of flood increases, which could adversely affect the water quality by contamination of water resources and/or damage the wells.

The most frequently reported potential impacts of identified risks in the direct operations and in the value chain

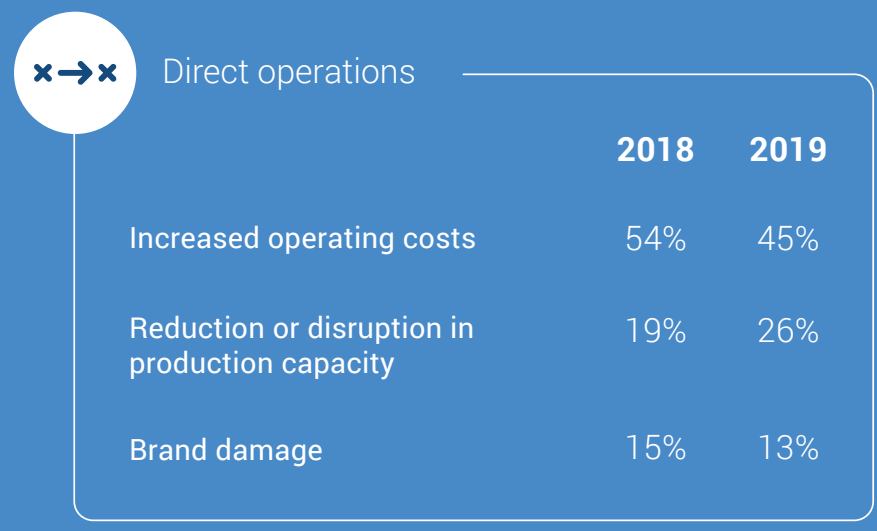

\begin{tabular}{lll}
\hline Value chain & $\mathbf{2 0 1 8}$ & $\mathbf{2 0 1 9}$ \\
& & \\
Supply chain disruption & $12 \%$ & $13 \%$ \\
$\begin{array}{l}\text { Reduction or disruption in } \\
\text { production capacity } \\
\text { Increased operating costs }\end{array}$ & $12 \%$ & $10 \%$ \\
\hline
\end{tabular}


$87 \%$

identified water-related opportunities and some/all are being realized

Minimum potential financial impact of the opportunity's calculation is based on the current loan disbursement for smart irrigation systems in Yapı Kredi's portfolio. Yapı Kredi cooperates with one of the biggest irrigation system companies in Turkey and foresees a maximum potential financial impact of the opportunity to be 5 million TRY for modern irrigation systems in the near future.

\section{$97 \%$}

have board-level oversight of waterrelated issues
In most parts of the world, water is cheap, with users often paying below-cost rates for their water supply. Only $16 \%$ of responding companies in Turkey cite higher water prices as a potential risk, either in their direct operations or along their supply chain.

There are also positive opportunities identified from taking action on water issues. 87 percent of responding companies identified water-related opportunities with the potential to have a substantive financial or strategic impact on the business and stated that some/ all are being realized. Efficiency $(71 \%)$ and markets (45\%) are the most reported types of opportunities currently being realized.

\section{\overnance}

The strategic decisions taken by the CEO and the Board can truly transform a company's impact on water resources. By providing board members with the information and tools to plan for a transition to a water-secure world and by publicly monitoring their progress, water stewardship can become part of companies' business strategy. Although companies report high levels of risk exposure and board-level oversight, they have not yet tied water issues to performance. 97 percent of companies report that they have board-level oversight of water-related issues within the organization. In more than half of the responding companies (52\%), CEO is the one with responsibility for water-related issues but only $58 \%$ have incentives in place for C-Suite executives on waterrelated issues.
We found that $81 \%$ ( $77 \%$ globally in 2018 ) report exposure to substantive water risks and $87 \%$ (81\% in 2018) of responding companies have company-wide water policy in Turkey. A further $90 \%$ engage in activities that could either directly or indirectly influence public policy on water.

\section{$52 \%$}

identified CEO with responsibility for water-related issues on the board

\section{$87 \%$}

\section{have a company-wide water policy}
Halk Bank's water policies and
procedures are set out in the Bank's
environmental policy. Reports and
works carried out throughout the
year are discussed at sustainability
committee meetings and presented to
the board of directors once a year.

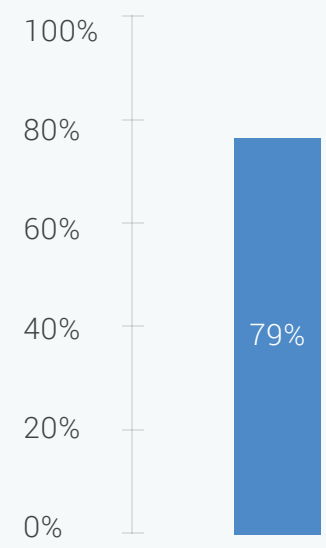

2015

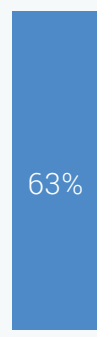

2016

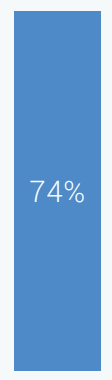

2017
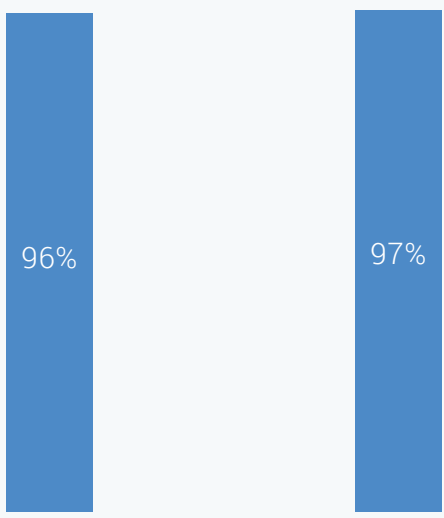

2018 
$74 \%$

\section{use climate-related scenario analysis}

ENKA uses International Energy

Agency (IEA) SD Scenario and Risk

assessment tools (WRI and Aqueduct)

for scenario/risk analysis. ENKA has

started to calculate water footprint

starting from 2016 and working on

setting a target for water consumption

for future years. ENKA also defined

sustainability strategy including

protecting environment and water

resources; set targets to reduce

water consumption in owned/leased

buildings.

\section{\ Business Strategy}

The purpose of this module is to collect information on how a company is adapting its long-term business model to secure a sustainable future, in terms of both its own resilience and securing water for all.

65 percent of responding companies identified water-related outcomes from the organization's climate-related scenario analysis. 74 percent of respondents use climate-related scenario analysis to inform its business strategy.

Only $19 \%$ (12\% in 2018 ) of companies use an internal price on water, which is lower than the companies that use an internal carbon price in Turkey (27\%).

Looking at the longer term $90 \%$ (88\% in 2018) of respondents in Turkey are integrating water-related issues into organization's long-term strategic business plan. A further $48 \%$ (38\% in 2018) integrated those issues into strategic business plan for more than 10 years.

\section{$94 \%$}

provided quantitative metric for water

\section{targets}

Vestel Beyaz Eşya aims to reduce water consumed in the manufacture of the products by $15 \%$ in 2022 . The company also set the goal of reducing water usage amount by $15 \%$ per water sourced from municipal supply compared to 2019 until 2030 to manage and reduce water consumption in domestic and overseas sites.

Percentage of companies integrated water-related issues into organization's strategic business plan

$90 \%$ Strategy for acchievng ||||||||||||||||||

\section{company-wide targets and goals in place to manage water risks}

Migros aims to reduce water

consumption by monitoring water

consumption on a monthly basis and

by using efficient equipment. Special

screens were developed for entering

the water consumption data from every

store on the intranet of the company.

The company started to monitor water

consumption per sales square meters in

order to track consumption. Compared

to our 2017 base year, company aimed

to reduce daily water consumption per

square meter sales area by $1 \%$ in 2018 ,

5\% in 2023 in the medium term, and 10\% until 2027 in the long term.

\section{$\mathbf{8 7 \%}$ objectives |||||||||||||||||| $\mid$}

Companies must set and achieve ambitious targets to reduce impacts on water availability and quality. There is an increased commitment of companies in Turkey on managing and sustaining water security. CDP defines a 'target' as a specific measurable output within a clear timeline, while a 'goal' aims to achieve a longer-term qualitative outcome or a specific change in behavior or circumstances. Targets are quantifiable objectives to manage water resources, and goals are qualitative aims leading towards improved water stewardship.

Most of the companies ( $90 \%, 85 \%$ in 2018 ) reporting this year have set companywide targets and goals in place to better manage water risks. 71 percent of responding companies achieved more than $50 \%$ of their water targets. This is a substantial increase from the $42 \%$ reporting the same last year.

\section{$77 \%$ Financial} ||||||||||||||||||||

\section{use an internal price on water}

Water withdrawals are the most common category of targets that are monitored at the corporate level (39\%). The most common category of water-related goals monitored at the corporate level are engagement with public policy makers to advance sustainable water management/ policies (19\%) and providing access to safely managed Water, Sanitation and Hygiene (WASH) in workplace (23\%). 


\section{Motivations behind the water-related targets and goals}

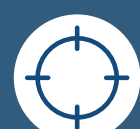

Targets

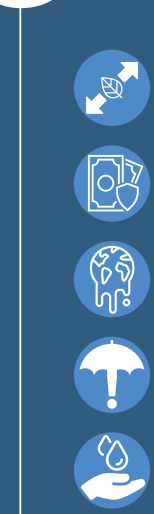

\section{ts}

Reduced environmental

Reduced environmental impacts

Cost savings

Climate change adaptation and mitigation strategies

Risk mitigation

Water stewardship

\section{8}

$42 \%$

$23 \%$

$58 \%$

(2)

$19 \%$

$12 \%$

$16 \%$

$12 \% \quad 13 \%$

$12 \%$

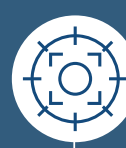

Goals

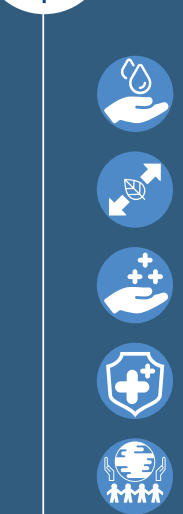

2018

2019

Water stewardship

$31 \% \quad 32 \%$

Reduced environmental

impacts

$23 \% \quad 29 \%$

Shared value

$23 \% \quad 26 \%$

Brand value protection

$15 \% \quad 13 \%$

Corporate social

responsibility

\section{$84 \%$}

identified linkages or trade-offs between water and other environmental issues
The percentage of respondents that provide quantitative metric for water targets is $94 \%$ ( $73 \%$ in 2018 ). A further $74 \%$ provide description of water goals.

Increasingly, companies will be required to manage water withdrawals, consumption, and discharges simultaneously with management of other environmental issues, e.g. energy consumption and greenhouse gas emissions. Linkage is a relationship where management of water has a positive impact on another environmental issue. On the other hand, trade-off is a relationship where management of water has a negative impact on another environmental issue.

84 percent of responding companies identified linkages or trade-offs between water and other environmental issues in the direct operations and/or other parts of the value chain. Increased energy use is the most common reported type of tradeoff $(29 \%)$ and as expected, decreased energy use is the most common reported type of linkage (26\%).

\footnotetext{
It is difficult for Brisa to control the quality of groundwater or third partysourced utility water, therefore they try to act pro-actively and invest in new technologies to minimize their dependency on external sources. A Wastewater Recovery Plant will become operational in 2020. This investment will enable them to recycle their process water and use it for cooling, which will reduce their water withdrawal.
}

Percentage of companies identified linkages or trade-offs between water and other environmental issues

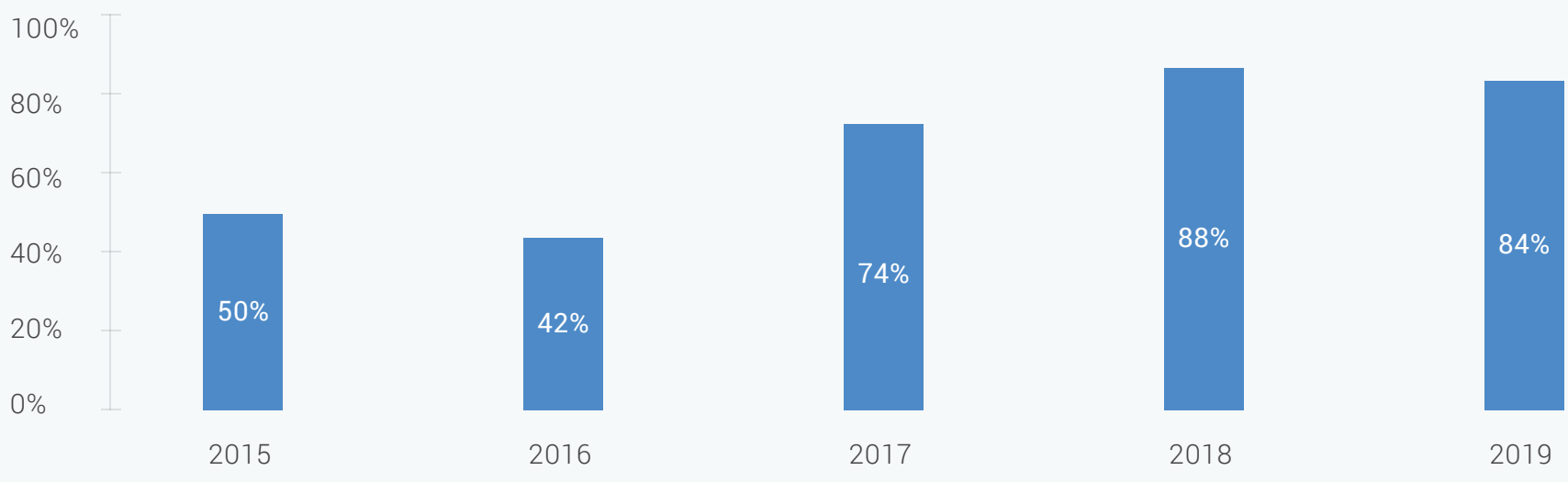




\section{CDP TURKEY LEADERS 2019}

TURKEY 2019

CDP Global Water A List

ETI SODA A.Ş.

CDP Turkey Climate Change Leaders

ARÇELIK A.Ş.

ASELSAN ELEKTRONIK SANAYI VE TICARET A.Ş.

BRISA BRIDGESTONE SABANCI LASTIK SAN. VE TIC. A.Ş.

MigROS TICARET A.Ş.

TEKFEN HOLDING A.Ş.

CDP Turkey Water Leaders

TEKFEN HOLDING A.Ş.

CDP Supplier Engagement Rating Leader
YAPI VE KREDI BANKASI A.Ş.

ACS Industry

Score

Materials

A

Manufacturing

A-

Manufacturing

A-

Manufacturing

A-

Retail

A-

Infrastructure

A-

Infrastructure

A-

Services

A-

Manufacturing

A

Score distribution of Turkey (Number of companies)
5

O
$\frac{1}{0}$
$\frac{0}{0}$
$\stackrel{0}{0}$
$\frac{1}{0}$

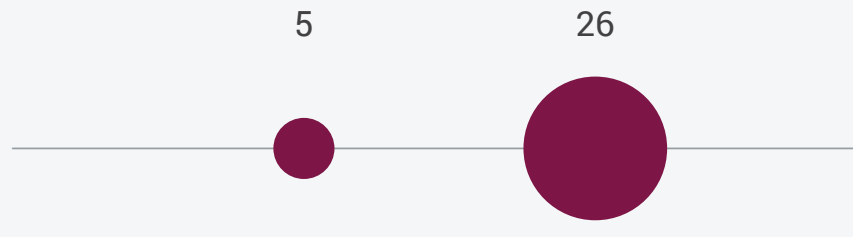

2

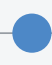

A-

B

B-

C

D 


\section{CDP Scoring Partners}

$\because$ ADEC INNOVATIONS ESG SOLUTIONS

\section{$\triangle$ DEKRA}

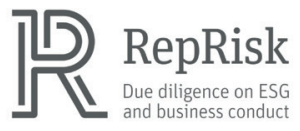

Further guidance on general questions and sector questions can be downloaded from: www.cdp.net/guidance/guidancefor-companies
CDP scoring lays down milestones marking the progress of a company's sustainable journey. It provides a roadmap to companies to compare themselves to the best in class. The scoring methodology has evolved over time to influence company behaviour in order to improve their environmental performance. Scoring at CDP is mission-driven, focusing on principles and values for a sustainable economy, and highlighting the business case for change.

CDP's 2019 questionnaires are focused on the high-impact sample companies in each of the three themes - Climate Change, Water, and Forests. To operationalise this approach, CDP developed a new Activity Classification System (CDP-ACS), ${ }^{7}$ a three-tiered system starting from the lower rung of Activity, going up to Activity Group and, finally, Industry. This framework categorizes companies by the most relevant sectors. It focuses on the diverse activities from which companies derive revenue and associates these with the impacts on their business from climate change, water security and deforestation. This helps ensure a better understanding of company actions according to their environmental risk, opportunity and impact and is essential for better comparability of data.

While the bulk of the scoring logic applies to all sectors and questionnaires alike, each of the questionnaires comes with a somewhat tailored scoring methodology. The sector-based approach allows CDP to make more meaningful assessments of companies' responses, incorporating each sector's characteristics and nuances, resulting in a score that reflects the company's progress in environmental stewardship and enabling better benchmarking against other companies.

The scoring of CDP's questionnaires is conducted by accredited scoring partners trained by CDP. CDP's internal scoring team coordinates and collates all scores and run data quality checks and quality assurance processes to ensure that

\section{Illustration of scoring levels}

Progress towards environmental stewardship

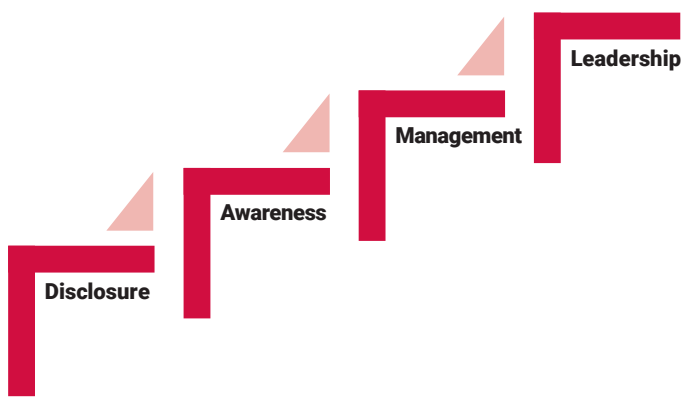

scoring standards are aligned between samples and scoring partners.

Responding companies are assessed across four consecutive levels which represent the steps a company moves through as it progresses towards environmental stewardship: Disclosure which measures the completeness of the company's response; Awareness which intends to measure the extent to which the company has assessed environmental issues, risks and impacts in relation to its business; Management which is a measure of the extent to which the company has implemented actions, policies and strategies to address environmental issues; and Leadership which looks for particular steps a company has taken which represent best practice in the field of environmental management.

Questions may include criteria for scoring across more than one level. The criteria for scoring the levels are distributed throughout the questionnaire. All of the questions are scored for the disclosure level. Some of the questions have no awareness, management or leadership level scoring associated with them.

\begin{tabular}{ccc}
$\begin{array}{c}\text { Climate } \\
\text { Change }\end{array}$ & Water & Forests \\
\hline$>64 \%$ & $>54 \%$ & $>60 \%$ \\
$0-64 \%$ & $0-54 \%$ & $1-59 \%$ \\
$45-75 \%$ & $45-75 \%$ & $45-65 \%$ \\
$<45 \%$ & $<45 \%$ \\
$45-79 \%$ & $45-79 \%$ \\
$<45 \%$ & $<45 \%$ \\
$45-79 \%$ & $45-79 \%$ \\
\hline
\end{tabular}
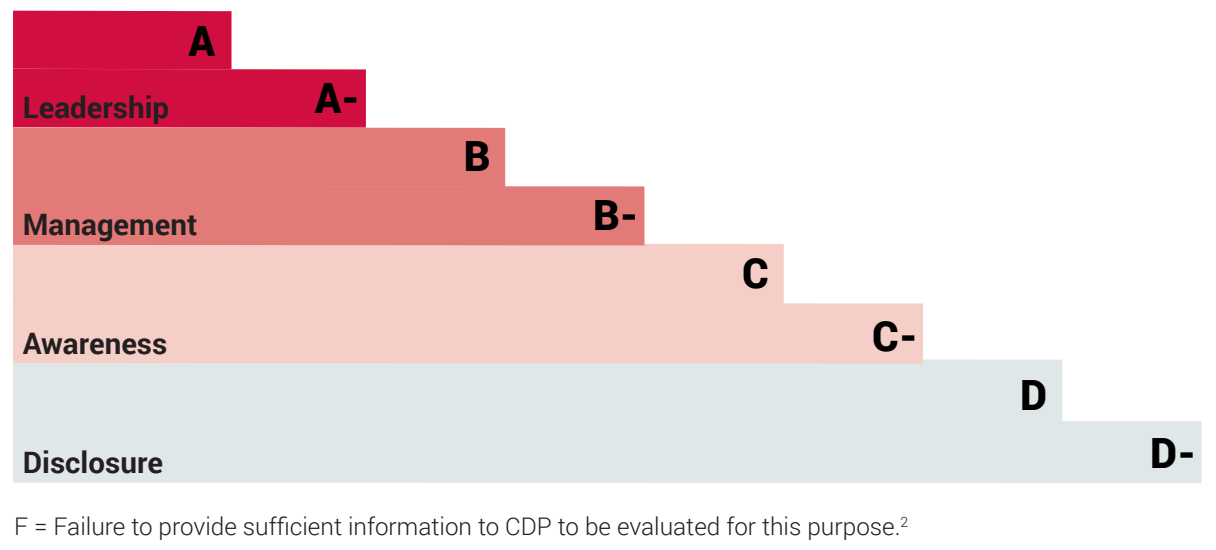


\section{Scoring categories and weightings}

Scoring categories in 2019 are sub-groups of the 2019 questionnaire modules and are unique to each theme, but within each theme they are consistent across all sectors. Each sector within each theme is affected by and manages environmental issues in a specific way. To capture these specificities, different weightings will be applied amongst sector scoring categories in each theme. ${ }^{3}$

Weightings are applied by calculating the Management and Leadership score per scoring category in the same way as previous years: Numerator/Denominator * 100 . These \% scores are then translated into a category score per level by calculating the proportion of points achieved relative to the category weighting: Category weighting (\%) / 100 * Management/Leadership score (\%). The category scores for each level are then summed together to calculate the overall final score.

Scoring weightings will only be applied to each of the scoring categories at Management and Leadership level. Where a scoring category consists of new questions, low weightings will reflect this. Weightings will be applied differently across sector categories for each theme to reflect this.

Public scores are available in CDP reports, through Bloomberg terminals, Google Finance and Deutsche Börse's website. CDP operates a strict conflict of interest policy with regards to scoring and this can be viewed at https://bit.ly/2Sx3hLd
1 For further information, visit https://bit.ly/2FlpQdY.

2 Not all companies requested to respond to CDP do so. Companies who are requested to disclose their data and fail to do so, or fail to provide sufficient information to CDP to be evaluated will receive an F. An F does not indicate a failure in environmental stewardship

3 The table is an example of the General Scoring methodology category weightings. Sector-wise scoring and the respective categories and weightings can be found here - https://bit.ly/2L70rF
Category

Management weighting

Leadership weighting

Governance

$12.0 \%$

$12.5 \%$

Risk management processes

$10.0 \%$

Risk Disclosure

$8.0 \%$

Opportunity Disclosure

$8.0 \%$

Business Impact Assessment \&

Financial Planning Assessment

Business Strategy

5

Scenario Analysis

5

Targets

12

Emissions reductions initiatives and

low carbon products

Scope 1 \& 2 emissions (incl. verification)

12

Scope 3 emissions (incl. verification)

5

Emissions breakdowns

0

Energy

6.0

7.0

Additional climate-related metrics (incl. verification)

Carbon pricing

2.0

0.0

Value chain engagement

5.0

Public policy engagement

1.0

0.0

Communications

1.0

0.5

Sign off

2.0

$100 \%$ Disclosure points

0.0

2.0

Overall Total

$100 \%$

$100 \%$ 
RESPONSE STATUS

CLIMATE CHANGE / TURKEY 2019

\section{CDP TURKEY CLIMATE CHANGE SAMPLE (BIST-100)}

\begin{tabular}{|c|c|c|c|c|c|c|c|}
\hline AFYON ÇIMENTO SANAYI T.A.Ş. & Cement & Materials & - & SA & $A Q$ & & \\
\hline AKBANK T.A.Ş. & General & Services & c & $A Q$ & $A Q$ & Public & $1,2,3$ \\
\hline AKENERJi ELEKTRIK ÜRETIM A.Ş. & Electric utilities & Power generation & B & $A Q$ & $A Q$ & Public & $1,2,3$ \\
\hline AKSA AKRILIKK KIMYA SANAYIi A.Ş. & Chemicals & Materials & B- & $A Q$ & $A Q$ & Non-public & $1,2,3$ \\
\hline AKSA ENERJI ÜRETIM A.Ş. & Electric utilities & Power generation & $\mathrm{F}$ & NR & DP & & \\
\hline ALARKO HOLDING A.Ş. & General & Infrastructure & $\mathrm{F}$ & NR & DP & & \\
\hline ALBARAKA TÜRK KATILIM BANKASI A.Ş. & General & Services & B & $A Q$ & $\mathrm{AQ}$ & Public & $1,2,3$ \\
\hline ANADOLU CAM SANAYii A.Ş. (T.ŞişE VE CAM FAB. A.Ş.) & General & Materials & - & SA & SA & & \\
\hline ANADOLU EFES BIRACILIK VE MALT SANAYIï A.Ş. & Food, beverage \& tobacco & Food, beverage $\&$ agriculture & c & $A Q$ & $A Q$ & Non-public & $1,2,3$ \\
\hline ANEL ELEKTRIK PROJE TAAHÜT VE TICARET A.Ş. & General & Infrastructure & $\mathrm{F}$ & DP & NR & & \\
\hline ARÇELIK A.Ş. & General & Manufacturing & A- & $A Q$ & $A Q$ & Public & $1,2,3$ \\
\hline ASELSAN ELEKTRONIK SANAYI VE TICARET A.Ş. & General & Manufacturing & A- & $A Q$ & $A Q$ & Public & $1,2,3$ \\
\hline AYGAZ A.Ş. & General & Fossil fuels & $\mathrm{F}$ & DP & NR & & \\
\hline BERA HOLDING A.Ş. & Paper \& forestry & Materials & $\mathrm{F}$ & DP & $\mathrm{x}$ & & \\
\hline BEŞiKTAŞ FUTBOL YATIRIMLARI SANAYI VE TICARET A.Ş. & General & Hospitality & $\mathrm{F}$ & NR & NR & & \\
\hline BIM BIRLEŞIK MAĞAZALAR A.Ş. & General & Retail & $\mathrm{F}$ & DP & DP & & \\
\hline BORUSAN MANNESMANN BORU SANAYI VE TICARET A.Ş. & Metals \& mining & Materials & $\mathrm{F}$ & DP & $x$ & & \\
\hline CARREFOURSA CARREFOUR SABANCI TICARET MERKEZI A.Ş. & General & Retail & $\mathrm{F}$ & DP & NR & & \\
\hline COCA-COLA IÇECEK A.Ş. & Food, beverage \& tobacco & Food, beverage $\&$ agriculture & B & $A Q$ & $\mathrm{AQ}$ & Public & $1,2,3$ \\
\hline ÇEMAŞ DÖKÜM SANAYI A.Ş. & Steel & Materials & $\mathrm{F}$ & DP & $x$ & & \\
\hline ÇEMTAŞ ÇELIK MAKINA SANAYI VE TICARET A.Ş. & Steel & Materials & $\mathrm{F}$ & DP & DP & & \\
\hline DENIZBANK A.Ş. & General & Services & $\mathrm{F}$ & DP & DP & & \\
\hline DEVA HOLDING A.Ş. & General & Biotech, health care \& pharma & $\mathrm{F}$ & NR & NR & & \\
\hline DOĞAN ŞIRKETLER GRUBU HOLDING A.Ş. & General & Services & $\mathrm{F}$ & NR & NR & & \\
\hline DOĞTAŞ KELEBEK MOBILYA SANAYI VE TICARET A.Ş. & General & Manufacturing & $\mathrm{F}$ & NR & $x$ & & \\
\hline DOĞUŞ OTOMOTIV SERVIS VE TICARET A.Ş. & General & Retail & $\mathrm{F}$ & DP & NR & & \\
\hline EGE ENDÜSTRI VE TICARET A.Ş. & General & Manufacturing & $\mathrm{F}$ & NR & NR & & \\
\hline EIS ECZACIBAŞI ILAÇ, SINAI VE FINANSAL YATIRIMLAR SAN. VE TiC. A.Ş. & General & Biotech, health care \& pharma & $\mathrm{F}$ & DP & NR & & \\
\hline ENERJISA ENERJI A.Ş. & Electric utilities & Infrastructure & NS & $A Q$ & $\mathrm{x}$ & Non-public & 1 \\
\hline ENKA INŞAAT VE SANAYI A.Ş. & Electric utilities & Power generation & B & $A Q$ & $\mathrm{AQ}$ & Public & $1,2,3$ \\
\hline EREĞLi DEMIR VE ÇELIK FABRIKALARI T.A.Ş. & Steel & Materials & $\mathrm{F}$ & NR & NR & & \\
\hline FENERBAHÇE FUTBOL A.Ş & General & Hospitality & $\mathrm{F}$ & DP & NR & & \\
\hline FLAP KONGRE TOPLANTI HIZMETLERI OTOMOTIV VE TURIZM A.Ş. & General & Services & $\mathrm{F}$ & NR & $\mathrm{x}$ & & \\
\hline FORD OTOMOTIV SANAYI A.Ş. & Transport OEMS & Manufacturing & B & $A Q$ & $A Q$ & Public & $1,2,3$ \\
\hline GALATASARAY SPORTIF SINAi VE YATIRIMLAR A.Ş. & General & Hospitality & $\mathrm{F}$ & DP & NR & & \\
\hline GERSAN ELEKTRIK TICARET VE SANAYI A.Ş. & General & Manufacturing & $\mathrm{F}$ & NR & $\mathrm{x}$ & & \\
\hline GLOBAL YATIRIM HOLDING A.Ş. & General & Transportation services & $\mathrm{F}$ & DP & NR & & \\
\hline GOODYEAR LASTIKLERI T.A.Ş. & General & Manufacturing & $\mathrm{F}$ & NR & NR & & \\
\hline GÖLTAŞ GÖLLER BÖLGESI ÇIMENTO SAN. VE TiC.A.Ş. & Cement & Materials & $\mathrm{F}$ & NR & NR & & \\
\hline GSD HOLDING A.Ş. & General & Services & $\mathrm{F}$ & DP & $A Q$ & & \\
\hline
\end{tabular}


RESPONSE STATUS

CLIMATE CHANGE / TURKEY 2019

CDP TURKEY CLIMATE CHANGE SAMPLE (BIST-100)

\begin{tabular}{|c|c|c|c|c|c|c|c|}
\hline GÜBRE FABRIKALARI T.A.Ş. & Chemicals & Materials & $\mathrm{F}$ & $\mathrm{DP}$ & NR & & \\
\hline HÜRRIYET GAZETECILIK VE MATBAACILIK A.Ş. & General & Services & $\mathrm{F}$ & $\mathrm{DP}$ & $\mathrm{DP}$ & & \\
\hline ICBC TURKEY BANK A.Ş. & General & Services & $\mathrm{F}$ & NR & $x$ & & \\
\hline IŞIKLAR ENERJI VE YAPI HOLDING A.Ş. & General & Manufacturing & $\mathrm{F}$ & $\mathrm{DP}$ & $x$ & & \\
\hline IHLAS GAYRIMENKUL PROJE GELIŞTIRME VE TICARET A.Ş. & General & Apparel & $\mathrm{F}$ & NR & $x$ & & \\
\hline iHLAS HOLDING A.Ş. & General & Infrastructure & $\mathrm{F}$ & NR & NR & & \\
\hline IPEK DOĞAL ENERJI KAYNAKLARI ARAŞTIRMA VE ÜRETIM A.Ş. & Oil \& gas & Fossil fuels & $\mathrm{F}$ & NR & NR & & \\
\hline ISKENDERUN DEMIR VE ÇELIK A.Ş. & Steel & Materials & $\mathrm{F}$ & NR & $x$ & & \\
\hline IŞ FINANSAL KIRALAMA A.Ş. & General & Services & $\mathrm{F}$ & NR & $x$ & & \\
\hline ITTIFAK HOLDING A.Ş. & General & Services & $\mathrm{F}$ & NR & $x$ & & \\
\hline KARDEMIR KARABÜK DEMIR ÇELIK SANAYI VE TICARET A.Ş. & Steel & Materials & D & $A Q$ & $A Q$ & Non-public & 1 \\
\hline KARSAN OTOMOTIV SANAYII VE TICARET A.Ş & Transport OEMS & Manufacturing & $\mathrm{F}$ & DP & NR & & \\
\hline KARTONSAN KARTON SANAYI VE TICARET A.Ş. & Paper \& forestry & Manufacturing & $\mathrm{F}$ & NR & NR & & \\
\hline KENT GIDA MADDELERI SANAYIi VE TICARET A.Ş. & Food, beverage \& tobacco & Food, beverage \& agriculture & $\mathrm{F}$ & NR & NR & & \\
\hline KOÇ HOLDING A.Ş. & Oil \& gas & Fossil fuels & $\mathrm{F}$ & NR & NR & & \\
\hline KORDSA TEKNIK TEKSTIL A.Ş. & General & Manufacturing & B & $A Q$ & $\mathrm{AQ}$ & Public & 1,2 \\
\hline KOZA ALTIN IŞLETMELERI A.Ş. & Metals \& mining & Materials & $\mathrm{F}$ & NR & NR & & \\
\hline KOZA ANADOLU METAL MADENCILIK IŞLETMELERI A.Ş. & Metals \& mining & Materials & $\mathrm{F}$ & NR & NR & & \\
\hline MAVI GIYIM SANAYI VE TICARET A.Ş. & General & Retail & $\mathrm{F}$ & NR & NR & & \\
\hline METRO TICARI VE MALI YATIRIMLAR HOLDING A.Ş. & Transport services & Transportation services & $\mathrm{F}$ & NR & NR & & \\
\hline MIGROS TICARET A.Ş. & General & Retail & A- & $A Q$ & $A Q$ & Public & $1,2,3$ \\
\hline MLP SAĞLIK HIZZMETLERI A.Ş. & General & Biotech, health care \& pharma & $\mathrm{F}$ & $\mathrm{DP}$ & $x$ & & \\
\hline NET HOLDING A.Ş. & General & Hospitality & $\mathrm{F}$ & DP & $x$ & & \\
\hline NETAŞ TELEKOMÜNIKASYON A.Ş. & General & Manufacturing & C & $A Q$ & $A Q$ & Non-public & $1,2,3$ \\
\hline ODAŞ ELEKTRIK ÜRETIM SANAYI TICARET A.Ş. & Electric utilities & Power generation & $\mathrm{F}$ & NR & NR & & \\
\hline OTOKAR OTOMOTIV VE SAVUNMA SANAYI A.Ş. & Transport OEMS & Manufacturing & $\mathrm{F}$ & NR & NR & & \\
\hline PARK ELEKTRIK ÜRETIM MADENCILIK SANAYI VE TICARET A.Ş. & Metals \& mining & Materials & $\mathrm{F}$ & NR & NR & & \\
\hline PEGASUS HAVA TAŞIMACILIĞI A.Ş. & Transport services & Transportation services & B & $\mathrm{AQ}$ & $A Q$ & Public & 1,2 \\
\hline PETKIM PETROKIMYA HOLDING A.Ş. & Chemicals & Materials & $\mathrm{F}$ & NR & NR & & \\
\hline QNB FINANSBANK A.Ş. & General & Services & $\mathrm{F}$ & NR & NR & & \\
\hline SABANCI HOLDING A.Ş. & General & Services & C & $A Q$ & DP & Public & $1,2,3$ \\
\hline SASA POLYESTER SANAYI A.Ş. & Other-base chemicals & Materials & $\mathrm{F}$ & NR & NR & & \\
\hline SODA SANAYI A.Ş. (T.ŞiŞE VE CAM FAB. A.Ş.) & Chemicals & Materials & - & SA & SA & & \\
\hline ŞEKERBANK T.A.Ş. & General & Services & B & $\mathrm{AQ}$ & $\mathrm{AQ}$ & Public & $1,2,3$ \\
\hline ŞOK MARKETLER TICARET A.Ş. & General & Retail & $\mathrm{F}$ & NR & $x$ & & \\
\hline T.GARANTI BANKASI A.Ş. & General & Services & B & $A Q$ & $\mathrm{AQ}$ & Public & $1,2,3$ \\
\hline T.IŞ BANKASI A.Ş. & General & Services & C & $A Q$ & NR & Public & $1,2,3$ \\
\hline T.SINAI KALKINMA BANKASI A.Ş. & General & Services & B & $A Q$ & $A Q$ & Public & $1,2,3$ \\
\hline T.ŞiŞE VE CAM FABRIKALARI A.Ş. & General & Materials & C & $A Q$ & $A Q$ & Public & 1,2 \\
\hline TAT GIDA SANAYii A.Ş. & Food, beverage \& tobacco & Food, beverage \& agriculture & $\mathrm{F}$ & NR & NR & & \\
\hline
\end{tabular}




\section{CDP TURKEY CLIMATE CHANGE SAMPLE (BIST-100)}

\begin{tabular}{|c|c|c|c|c|c|c|c|}
\hline TAV HAVA LIMANLARI HOLDING A.Ş. & General & Services & C & $A Q$ & $A Q$ & Public & $1,2,3$ \\
\hline TEKFEN HOLDING A.Ş. & General & Infrastructure & $A^{-}$ & $A Q$ & $A Q$ & Public & $1,2,3$ \\
\hline TOFAŞ TÜRK OTOMOBIL FABRIKASI A.Ş. & Transport OEMS & Manufacturing & B- & $A Q$ & $A Q$ & Public & $1,2,3$ \\
\hline TRAKYA CAM SANAYIi A.Ş. (T.ŞiŞE VE CAM FAB. A.Ş.) & General & Materials & - & SA & SA & & \\
\hline TURCAS PETROL A.Ş. & Electric utilities & Power generation & $\mathrm{F}$ & DP & NR & & \\
\hline TURKCELL ILETIŞSiM HIZMETLERI A.Ş. & General & Services & C & $A Q$ & $A Q$ & Public & $1,2,3$ \\
\hline TÜMOSAN MOTOR VE TRAKTÖR SANAYI A.Ş. & General & Manufacturing & $\mathrm{F}$ & NR & NR & & \\
\hline TÜPRAŞ - TÜRKIYE PETROL RAFINERILERI A.Ş. & Oil \& gas & Fossil fuels & $\mathrm{F}$ & NR & NR & & \\
\hline TÜRK HAVA YOLLARI A.O. & Transport services & Transportation services & $\mathrm{F}$ & DP & NR & & \\
\hline TÜRK TELEKOMÜNIKASYON A.Ş. & General & Services & B & $A Q$ & $A Q$ & Non-public & $1,2,3$ \\
\hline TÜRK TRAKTÖR VE ZIRAAT MAKINELERI A.Ş. & General & Manufacturing & $\mathrm{F}$ & DP & NR & & \\
\hline TÜRK TUBORG BIRA VE MALT SANAYI A.Ş. & Food, beverage \& tobacco & Food, beverage \& agriculture & $\mathrm{F}$ & DP & NR & & \\
\hline TÜRKIYE HALK BANKASI A.Ş. & General & Services & B & $A Q$ & $A Q$ & Public & $1,2,3$ \\
\hline TÜRKIYE KALKINMA VE YATIRIM BANKASI A.Ş. & General & Services & B & $A Q$ & DP & Public & $1,2,3$ \\
\hline TÜRKIYE VAKIFLAR BANKASI T.A.O. & General & Services & B & $\mathrm{AQ}$ & $A Q$ & Public & $1,2,3$ \\
\hline ÜLKER BISKÜVI SANAYI A.Ş. & Food, beverage \& tobacco & Food, beverage \& agriculture & $\mathrm{C}$ & $A Q$ & DP & Non-public & $1,2,3$ \\
\hline VESTEL ELEKTRONIK SANAYI VE TICARET A.Ş. & General & Manufacturing & C & $\mathrm{AQ}$ & $A Q$ & Public & $1,2,3$ \\
\hline YAPI VE KREDI BANKASI A.Ş. & General & Services & B & $A Q$ & $\mathrm{AQ}$ & Public & $1,2,3$ \\
\hline YATAŞ YATAK VE YORGAN SANAYI VE TICARET A.Ş. & General & Manufacturing & $\mathrm{F}$ & NR & NR & & \\
\hline ZORLU ENERJI ELEKTRIK ÜRETIM A.Ş. & Electric utilities & Power generation & B & $A Q$ & $A Q$ & Public & $1,2,3$ \\
\hline \multicolumn{8}{|l|}{ OTHER RESPONDING COMPANIES } \\
\hline AKÇANSA ÇIMENTO SANAYI VE TICARET A.Ş. & Cement & Materials & B & $A Q$ & $A Q$ & Public & $1,2,3$ \\
\hline BRISA BRIDGESTONE SABANCI LASTIK SAN. VE TIC. A.Ş. & General & Manufacturing & $A^{-}$ & $\mathrm{AQ}$ & $A Q$ & Public & $1,2,3$ \\
\hline ÇELEBI HAVA SERVISI A.Ş. & General & Services & C & $A Q$ & $\mathrm{AQ}$ & Non-public & 1,2 \\
\hline ÇIMSA ÇIMENTO SANAYIi VE TICARET A.Ş. & Cement & Materials & B & $A Q$ & $A Q$ & Public & $1,2,3$ \\
\hline DURAN DOĞAN BASIM VE AMBALAJ A.Ş. & General & Manufacturing & B & $A Q$ & $A Q$ & Non-public & $1,2,3$ \\
\hline EKOTEN SANAYI VE TEKSTIL A.Ş. & General & Apparel & B & $A Q$ & $A Q$ & Public & $1,2,3$ \\
\hline ETI SODA A.Ş. & Metals \& mining & Materials & B & $A Q$ & $x$ & Public & $1,2,3$ \\
\hline IHLAS EV ALETLERI IMALAT SANAYI VE TICARET A.Ş. & General & Manufacturing & NS & $A Q$ & $x$ & Non-public & $1,2,3$ \\
\hline KAYSERI ULAŞIM A.Ş. & Transport services & Transportation services & B & $A Q$ & $\mathrm{AQ}$ & Public & $1,2,3$ \\
\hline PINAR ENTEGRE ET VE UN SANAYIi A.Ş. & Food, beverage \& tobacco & Food, beverage $\&$ agriculture & B & $\mathrm{AQ}$ & $A Q$ & Non-public & $1,2,3$ \\
\hline PINAR SÜT MAMULLERI SANAYIi A.Ş. & Food, beverage \& tobacco & Food, beverage \& agriculture & B & $A Q$ & $A Q$ & Non-public & $1,2,3$ \\
\hline POLISAN HOLDING A.Ş. & Chemicals & Materials & $\mathrm{D}$ & $A Q$ & $\mathrm{AQ}$ & Non-public & 1,2 \\
\hline SUN TEKSTIL SANAYI VE TICARET A.Ş. (EKOTEN SA. VE TEKSTIL A.Ş.) & General & Apparel & - & SA & SA & & \\
\hline VESTEL BEYAZ EŞYA SANAYI VE TICARET A.Ş. & General & Manufacturing & C & $A Q$ & $A Q$ & Public & $1,2,3$ \\
\hline YÜNSA YÜNLÜ SANAYI VE TICARET A.Ş. & General & Apparel & B & $A Q$ & $\mathrm{AQ}$ & Public & $1,2,3$ \\
\hline ZORLU DOĞAL ELEKTRIK ÜRETIMI A.Ş. & Electric utilities & Power generation & B & $A Q$ & $A Q$ & Public & $1,2,3$ \\
\hline
\end{tabular}

Key to Response Status Tables

(AQ) Answered questionnaire, (NR) No response, (DP) Declined to Participate, (F) Failure to provide sufficient information to CDP to be evaluated for this purpose, (X) Company was not included in any CDP samples in that year, (SA) Company is either a subsidiary or the parent company is already responding to CDP, (NS) Not scored since responding short version of the questionnaire. See company in brackets for further information on company status. 
RESPONSE STATUS

WATER SECURITY / TURKEY 2019

COMPANY - REQUESTED

PRIMARY QUESTIONNAIRE

ACS INDUSTRY

CDP TURKEY WATER SAMPLE

\begin{tabular}{|c|c|c|c|c|c|c|c|c|c|}
\hline AFYON ÇIMENTO SANAYI T.A.Ş. & Materials & Materials & - & SA & DP & & & & \\
\hline AKENERJi ELEKTRIK ÜRETIM A.Ş. & Utilities & Power generation & B- & $A Q$ & $A Q$ & Public & D & D & D \\
\hline AKSA AKRILIK KIMYA SANAYIi A.Ş. & Consumer discretionary & Materials & B & $A Q$ & $A Q$ & Non-public & D & D & D \\
\hline AKSA ENERJI ÜRETIM A.Ş. & Utilities & Power generation & $\mathrm{F}$ & NR & DP & & & & \\
\hline ALARKO HOLDING A.Ş. & Industrials & Infrastructure & $\mathrm{F}$ & NR & DP & & & & \\
\hline ANADOLU CAM SANAYIi A.Ş. & Materials & Materials & $\mathrm{F}$ & NR & DP & & & & \\
\hline ANADOLU EFES BIRACILIK VE MALT SANAYIi A.Ş. & Consumer staples & Food, beverage \& agriculture & $\mathrm{F}$ & NR & NR & & & & \\
\hline ARÇELIK A.Ş. & Consumer discretionary & Manufacturing & B & $A Q$ & $A Q$ & Public & D & $\mathrm{D}$ & $\mathrm{D}$ \\
\hline ASELSAN ELEKTRONIK SANAYI VE TICARET A.Ş. & Industrials & Manufacturing & $\mathrm{F}$ & NR & NR & & & & \\
\hline AYGAZ A.Ş. & Utilities & Fossil fuels & $\mathrm{F}$ & DP & NR & & & & \\
\hline BERA HOLDING A.Ş. & Industrials & Materials & $\mathrm{F}$ & DP & $\mathrm{x}$ & & & & \\
\hline BIM BIRLEŞiK MAĞAZALAR A.Ş. & Consumer staples & Retail & $\mathrm{F}$ & DP & DP & & & & \\
\hline BORUSAN MANNESMANN BORU SANAYI VE TICARET A.Ş. & Industrials & Materials & $\mathrm{F}$ & DP & NR & & & & \\
\hline BRISA BRIDGESTONE SABANCI LASTIK SAN. VE TIC. A.Ş. & Consumer discretionary & Manufacturing & B & $A Q$ & $A Q$ & Public & D & D & $\mathrm{D}$ \\
\hline CARREFOURSA CARREFOUR SABANCI TICARET MERKEZI A.Ş. & Consumer staples & Retail & $\mathrm{F}$ & DP & NR & & & & \\
\hline COCA-COLA IÇECEK A.Ş. & Consumer staples & Food, beverage \& agriculture & B & $A Q$ & $A Q$ & Public & D & $\mathrm{D}$ & $\mathrm{D}$ \\
\hline ÇIMSA ÇIMENTO SANAYii VE TICARET A.Ş. & Materials & Materials & B & $A Q$ & $A Q$ & Public & D & $\mathrm{D}$ & $\mathrm{D}$ \\
\hline DOĞAN ŞIRKETLER GRUBU HOLDING A.Ş. & Industrials & Services & $\mathrm{F}$ & NR & $x$ & & & & \\
\hline EIS ECZACIBAŞI ILAÇ, SINAI VE FIN. YAT. SAN. VE TiC. A.Ş.. & Health care & Biotech, health care \& pharma & $\mathrm{F}$ & DP & NR & & & & \\
\hline ENERJISA ENERJI A.Ş. & Utilities & Infrastructure & $\mathrm{F}$ & NR & $x$ & & & & \\
\hline ENKA INŞAAT VE SANAYI A.Ş. & Industrials & Power generation & B & $A Q$ & $A Q$ & Public & D & D & $\mathrm{D}$ \\
\hline EREĞLi DEMIR VE ÇELIK FABRIKALARI T.A.Ş. & Materials & Materials & $\mathrm{F}$ & NR & NR & & & & \\
\hline FORD OTOMOTIV SANAYI A.Ş. & Consumer discretionary & Manufacturing & B & $A Q$ & $A Q$ & Public & D & D & D \\
\hline GOODYEAR LASTIKLERI T.A.Ş. & Consumer discretionary & Manufacturing & $\mathrm{F}$ & NR & NR & & & & \\
\hline GÜBRE FABRIKALARI T.A.Ş. & Materials & Materials & $\mathrm{F}$ & DP & NR & & & & \\
\hline IHLAS HOLDING A.Ş. & Industrials & Infrastructure & $\mathrm{F}$ & NR & $x$ & & & & \\
\hline ISKENDERUN DEMIR VE ÇELIK A.Ş. & Materials & Materials & $\mathrm{F}$ & NR & $x$ & & & & \\
\hline KARDEMIR KARABÜK DEMIR ÇELIK SANAYI VE TICARET A.Ş. & Materials & Materials & $\mathrm{F}$ & NR & DP & & & & \\
\hline KOÇ HOLDING A.Ş. & Industrials & Fossil fuels & $\mathrm{F}$ & NR & NR & & & & \\
\hline KORDSA TEKNIK TEKSTIL A.Ş. & Consumer discretionary & Manufacturing & B & $A Q$ & $A Q$ & Public & D & D & D \\
\hline KOZA ALTIN IŞLETMELERI A.Ş. & Materials & Materials & $\mathrm{F}$ & NR & NR & & & & \\
\hline KOZA ANADOLU METAL MADENCILIK IŞLETMELERI A.Ş. & Materials & Materials & $\mathrm{F}$ & NR & NR & & & & \\
\hline MIGROS TICARET A.Ş. & Consumer staples & Retail & B & $A Q$ & $A Q$ & Public & D & $\mathrm{D}$ & $\mathrm{D}$ \\
\hline NET HOLDING A.Ş. & Consumer discretionary & Hospitality & $\mathrm{F}$ & DP & NR & & & & \\
\hline OTOKAR OTOMOTIV VE SAVUNMA SANAYI A.Ş. & Industrials & Manufacturing & $\mathrm{F}$ & NR & NR & & & & \\
\hline POLISAN HOLDING A.Ş. & Materials & Materials & C & $A Q$ & $A Q$ & Non-public & D & D & D \\
\hline
\end{tabular}


RESPONSE STATUS

WATER SECURITY / TURKEY 2019

\begin{tabular}{|c|c|c|c|c|c|c|c|c|c|}
\hline COMPANY - REQUESTED & PRIMARY QUESTIONNAIRE & ACS INDUSTRY & & & & & & & \\
\hline \multicolumn{10}{|l|}{ CDP TURKEY WATER SAMPLE } \\
\hline SASA POLYESTER SANAYI A.Ş. & Materials & Materials & $\mathrm{F}$ & NR & $\mathrm{x}$ & & & & \\
\hline SODA SANAYI A.Ş. & Materials & Materials & $\mathrm{F}$ & NR & DP & & & & \\
\hline T.ŞiŞE VE CAM FABRIKKALARI A.Ş. & Industrials & Materials & $\mathrm{F}$ & NR & DP & & & & \\
\hline TEKFEN HOLDING A.Ş. & Industrials & Infrastructure & A- & $A Q$ & $A Q$ & Public & D & $\mathrm{D}$ & $\mathrm{D}$ \\
\hline TOFAŞ TÜRK OTOMOBIL FABRIKASI A.Ş. & Consumer discretionary & Manufacturing & B- & $A Q$ & $\mathrm{AQ}$ & Public & D & D & D \\
\hline TRAKYA CAM SANAYII A.Ş. & Industrials & Materials & $\mathrm{F}$ & NR & DP & & & & \\
\hline TÜMOSAN MOTOR VE TRAKTÖR SANAYI A.Ş. & Industrials & Manufacturing & $\mathrm{F}$ & NR & NR & & & & \\
\hline TÜPRAŞ -TÜRKIYE PETROL RAFINERILERI A.Ş. & Energy & Fossil fuels & $\mathrm{F}$ & NR & NR & & & & \\
\hline TÜRK TRAKTÖR VE ZIRAAT MAKINELERI A.Ş. & Industrials & Manufacturing & $\mathrm{F}$ & DP & NR & & & & \\
\hline TÜRK TUBORG BIRA VE MALT SANAYI A.Ş. & Consumer staples & Food, beverage \& agriculture & $\mathrm{F}$ & DP & NR & & & & \\
\hline ÜLKER BISKÜVI SANAYI A.Ş. & Consumer staples & Food, beverage \& agriculture & C & $A Q$ & DP & Public & D & $\mathrm{D}$ & $\mathrm{D}$ \\
\hline VESTEL BEYAZ EŞYA SANAYI VE TICARET A.Ş. & Consumer discretionary & Manufacturing & B- & $A Q$ & $A Q$ & Public & $\mathrm{D}$ & $\mathrm{D}$ & $\mathrm{D}$ \\
\hline VESTEL ELEKTRONIK SANAYI VE TICARET A.Ş. & Consumer discretionary & Manufacturing & B- & $A Q$ & DP & Public & D & $\mathrm{D}$ & $\mathrm{D}$ \\
\hline ZORLU ENERJI ELEKTRIK ÜRETIM A.Ş. & Utilities & Power generation & B- & $A Q$ & $A Q$ & Public & D & D & D \\
\hline
\end{tabular}

\section{OTHER RESPONDING COMPANIES}

\begin{tabular}{|c|c|c|c|c|c|c|c|c|c|}
\hline AKÇANSA ÇIMENTO SANAYI VE TICARET A.Ş. & Materials & Materials & C & $A Q$ & $A Q$ & Public & $\mathrm{D}$ & $\mathrm{D}$ & $\mathrm{D}$ \\
\hline ALBARAKA TÜRK KATILIM BANKASI A.Ş. & Financials & Services & B- & $A Q$ & $\mathrm{AQ}$ & Public & $\mathrm{D}$ & D & $\mathrm{D}$ \\
\hline DURAN DOĞAN BASIM VE AMBALAJ A.Ş. & Materials & Manufacturing & B- & $A Q$ & $\mathrm{AQ}$ & Non-public & & & \\
\hline ETI SODA A.Ş. & Materials & Materials & A & $A Q$ & $x$ & Public & $\mathrm{D}$ & D & $\mathrm{D}$ \\
\hline IHLAS EV ALETLERI IMALAT SANAYI VE TICARET A.Ş. & Consumer discretionary & Manufacturing & NS & $\mathrm{AQ}$ & $x$ & Non-public & & & \\
\hline PINAR ENTEGRE ET VE UN SANAYIi A.Ş. & Consumer staples & Food, beverage \& agriculture & B & $A Q$ & $A Q$ & Non-public & $\mathrm{D}$ & $\mathrm{D}$ & $\mathrm{D}$ \\
\hline PINAR SÜT MAMULLERI SANAYIi A.Ş. & Consumer staples & Food, beverage \& agriculture & B & $A Q$ & $\mathrm{AQ}$ & Non-public & D & D & $\mathrm{D}$ \\
\hline SABANCI HOLDING A.Ş. & Financials & Services & B- & $A Q$ & $x$ & Public & $\mathrm{D}$ & D & $\mathrm{D}$ \\
\hline ŞEKERBANK T.A.Ş. & Financials & Services & B- & $A Q$ & $A Q$ & Public & $\mathrm{D}$ & D & $\mathrm{D}$ \\
\hline T.GARANTI BANKASI A.Ş. & Financials & Services & B- & $A Q$ & $A Q$ & Public & D & $\mathrm{D}$ & $\mathrm{D}$ \\
\hline TÜRKIYE HALK BANKASI A.Ş. & Financials & Services & B- & $A Q$ & $\mathrm{AQ}$ & Public & $\mathrm{D}$ & D & $\mathrm{D}$ \\
\hline YAPI VE KREDI BANKASI A.Ş. & Financials & Services & $A^{-}$ & $A Q$ & $\mathrm{AQ}$ & Public & D & D & $\mathrm{D}$ \\
\hline YÜNSA YÜNLÜ SANAYI VE TICARET A.Ş. & Consumer discretionary & Apparel & B- & $A Q$ & $A Q$ & Public & D & D & $\mathrm{D}$ \\
\hline ZORLU DOĞAL ELEKTRIK ÜRETIMI A.Ş. & Energy & Power generation & B- & $A Q$ & $A Q$ & Public & D & D & D \\
\hline
\end{tabular}

\section{Key to Response Status Tables}

(AQ) Answered questionnaire, (NR) No response, (DP) Declined to Participate, (F) Failure to provide sufficient information to CDP to be evaluated for this purpose, (X) Company was not included in any CDP samples in that year, (SA) Company is either a subsidiary or the parent company is already responding to CDP, (NS) Not scored since responding short version of the questionnaire. See company in brackets for further information on company status. 


\section{CDP PARTNER IN TURKEY \\ Sabancı University Corporate Governance Forum}

\section{Team Members}

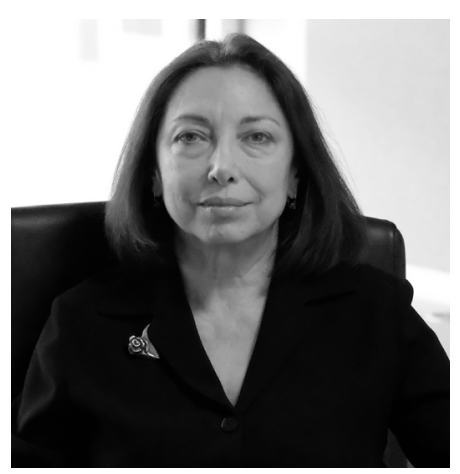

Melsa Ararat CDP Director

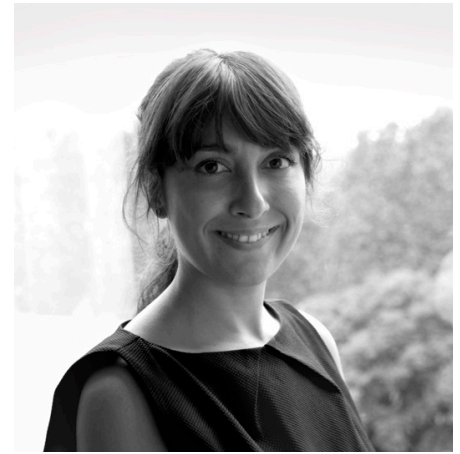

Mirhan Köroğlu Göğüş CDP Projects Manager

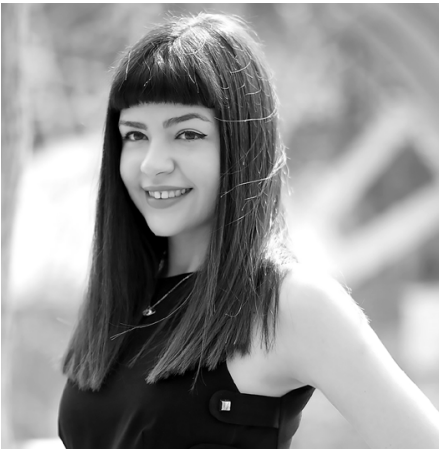

Firuze Alpaydın

CDP Project Officer

\section{Important Notice}

The contents of this report may be used by anyone providing acknowledgement is given to CDP Worldwide (CDP). This does not represent a license to repackage or resell any of the data reported to CDP or the contributing authors and presented in this report. If you intend to repackage or resell any of the contents of this report, you need to obtain express permission from CDP before doing so.

Sabancı University Corporate Governance Forum and CDP have prepared the data and analysis in this report based on responses to the CDP 2019 information request. No representation or warranty (express or implied) is given by Sabancı University Corporate Governance Forum or CDP as to the accuracy or completeness of the information and opinions contained in this report. You should not act upon the information contained in this publication without obtaining specific professional advice. To the extent permitted by law, Sabancı University Corporate Governance Forum and CDP do not accept or assume any liability, responsibility or duty of care for any consequences of you or anyone else acting, or refraining to act, in reliance on the information contained in this report or for any decision based on it. All information and views expressed herein by CDP and/or Sabancı University Corporate Governance Forum is based on their judgment at the time of this report and are subject to change without notice due to economic, political, industry and firm-specific factors. Guest commentaries where included in this report reflect the views of their respective authors; their inclusion is not an endorsement of them.

Sabancı University Corporate Governance Forum and CDP and their affiliated member firms or companies, or their respective shareholders, members, partners, principals, directors, officers and/or employees, may have a position in the securities of the companies discussed herein. The securities of the companies mentioned in this document may not be eligible for sale in some states or countries, nor suitable for all types of investors; their value and the income they produce may fluctuate and/or be adversely affected by exchange rates.

'CDP Worldwide' and 'CDP' refer to CDP Worldwide, a registered charity number 1122330 and a company limited by guarantee, registered in England number 05013650.

(c) 2019 CDP Worldwide. All rights reserved.

DOI number. 10.5900/SU_SOM_WP.2020.39726 
CDP Contacts

Sue Howells

Chief Operating Officer

\section{Antigone Theodorou}

Director, Asia Pacific,

Latin America and

Partner Regions

\section{Ji Yeon Kim}

Manager, Partner Regions

\section{CDP Worldwide}

4th Floor Plantation Place South

60 Great Tower Street

London EC3R 5AD

Telephone: +44 (0) 2038183900

www.cdp.net

\section{Partner Contacts}

Melsa Ararat

Director

\section{Mirhan Köroğlu Göğüş}

Projects Manager

\section{Sabancı University}

Orhanlı/Tuzla 34956

Istanbul Turkey

Tel: +90 (0) 2164839682

cdpturkey.sabanciuniv.edu

mirhan.koroglu@sabanciuniv.edu
Report Writer Contacts

Mirhan Köroğlu Göğüş

CDP Turkey

Melsa Ararat

CDP Turkey

Firuze Alpaydın

CDP Turkey

\author{
Report Design \\ Duygu Serin \\ Artimprojects \\ Efe Serin \\ Artimprojects
}

